\title{
Comparison of modern and ancient Vertisols developed on limestone in terms of their geochemistry and parent material
}

\author{
Steven G. Driese ${ }^{\mathrm{a}, *}$, Joseph R. Jacobs ${ }^{\mathrm{a}}$, Lee C. Nordt ${ }^{\mathrm{b}}$ \\ ${ }^{a}$ Department of Geological Sciences, University of Tennessee, Knoxville, TN 37996-1410, USA \\ ${ }^{\mathrm{b}}$ Department of Geology, Baylor University, Waco, TX, 76798-7354 USA
}

Received 10 August 2001; accepted 29 March 2002

\begin{abstract}
Identification of paleosol parent material can be difficult; a common simplistic assumption is that nonpedogenic strata directly beneath paleosols are representative of the parent material. Field relationships, petrography, and geochemical massbalance were used to test the simple hypothesis that the parent material of both an Early Carboniferous (Late Mississippian) vertic (Vertisol-like) paleosol and a modern analog soil (Vertisol) was immediately subjacent marine carbonate rock. An alternative hypothesis also tested was that the paleosol formed primarily from siliciclastic sediment deposited on top of the carbonate. The modern-ancient analog comparison is valid because both the paleosol and the modern soil have high clay contents, extensive shrink-swell features, and rest directly on top of marine carbonate substrates. Field and thin-section observations indicate minor assimilation of marine carbonate into both the paleosol and soil matrices. Mass-balance of both the paleosol and soil, calculated assuming that the subjacent carbonate was the parent material and that Ti was immobile during weathering, indicated $25-75 \%$ net volume loss during weathering and $25-99 \%$ net losses of many alkali, alkaline earth, and redox-sensitive elements. However, calculations based on an alternative hypothesis of clayshale parent material for the paleosol indicated only $10-25 \%$ volume loss and lower translocation losses for weathering of this material. The insoluble residue content of the dolostone would require that a fourfold volume reduction during weathering occurred, if the dolostone were the only parent material. If the paleosol formed from clayshale, then significantly less volume loss characterised weathering. These results collectively illustrate that the simplest interpretation of paleosol parent material may not always be correct, and that paleosols can be derived from weathering of more than one parent material.
\end{abstract}

(C) 2002 Elsevier Science B.V. All rights reserved.

Keywords: Paleosols; Lower Carboniferous; Mass-balance; Geochemistry; Vertisols

\section{Introduction}

Identification of the parent material of soils and paleosols can be difficult to establish (Birkeland,

\footnotetext{
* Corresponding author. Tel.: +1-865-974-6002; fax: +1-865974-2368.

E-mail address: sdriese@utk.edu (S.G. Driese).
}

1999; Retallack, 2001). The simplest assumption is that the nonpedogenic strata directly underlying paleosols are representative of the parent material. Correct identification of parent material is important and is critical to the assessment of weathering, in both modern soils and in lithified paleosols, using the procedure known as mass-balance reconstruction, which was developed in a series of seminal papers 
by Brimhall et al. (1988, 1991a,b). Soil systems are generally dynamic and open to influxes of new material due to geologic processes such as volcanic and volcaniclastic inputs (e.g., Ashley and Driese, 2000), aeolian inputs (e.g., Mason and Jacobs, 1998), and fluvial inputs (e.g., Birkeland, 1999). This paper explores these issues by testing the hypothesis that the parent material of both an Early Carboniferous (Late Mississippian) vertic (Vertisollike) paleosol and a modern analog soil (Vertisol) was subjacent marine carbonate rock vs. an alternative hypothesis that the paleosol formed primarily from siliciclastic sediment deposited on top of the carbonate.

The purpose of this study is to use field, thin section and geochemical data for determining if the assumption of a dominantly carbonate parent material for clay-rich soils and paleosols that directly overlie carbonate rocks is correct. Specifically, we will examine whether the parent material of a single graygreen, vertic claystone paleosol that occurs in the lower portion of the Pennington Formation (Lower Carboniferous, Upper Mississippian) of eastern Tennessee, USA, formed from weathered carbonate or from weathered siliciclastic material, using a modern analog soil from Texas for a process comparison (Appendix A). The claystone paleosol is sandwiched between two subtidal marine dolostone beds. The results support our contention that the paleosol probably formed from weathering of clay sediment deposited on top of the subjacent dolostone, and that the modern soil may also have received fluvial inputs during pedogenesis.

\section{Background information}

Caudill et al. (1992, 1996, 1997), Mora and Driese (1999), and Driese et al. (2000) previously described paleosols in the Pennington Formation of eastern Tennessee. The Pennington paleosols exhibit pronounced vertic (shrink-swell) features, including gilgai (surface micro-relief), slickensides, angular blocky to wedge-shaped aggregates (parallelipipeds), and sepic-plasmic (bright clay) microfabrics, and are considered broadly analogous to modern Vertisols of USDA Soil Taxonomy (Soil Survey Staff, 1998). Modern Vertisols are high clay-content soils $(>30 \%$ clay) with a high shrink-swell potential that form in seasonally wet-dry climates, or in regions with a seasonal high soil-moisture deficit (Dudal and Eswaran, 1988; Coulombe et al., 1996).

Caudill et al. (1996) estimated palaeoprecipitation for a well-preserved Pennington paleosol as about $65 \pm 14 \mathrm{~cm} /$ year, based on reconstructed depth to the calcic (Bk) horizon, using the functional relationship developed by Retallack (1994) from many types of modern soils. Stiles et al. (2001) estimated palaeoprecipitation for two Pennington paleosols as ranging from 96 to $112 \mathrm{~cm} /$ year based on the total $\mathrm{Fe}$ content of $\mathrm{Fe} / \mathrm{Mn}$ nodules in the paleosols, and preserved depth to Bk horizon, using functional relationships developed specifically from modern Vertisols in Texas. The palaeoclimate in Tennessee during Early Carboniferous (Mississippian) time can therefore be characterised as semiarid to subhumid. Palaeogeographic reconstructions for the Early Carboniferous locate Tennessee at $5-10^{\circ}$ south palaeolatitude (Scotese et al., 1979; Ziegler et al., 1979). This palaeolatitude, in conjunction with strongly seasonal precipitation or seasonally high soil-moisture deficits and abundant sources of weatherable clays, promoted soil genesis via periodic expansion and contraction of the soil associated with wetting and drying cycles, which are diagnostic of modern Vertisol pedogenic processes (Dudal and Eswaran, 1988; Coulombe et al., 1996). Palaeoatmospheric $p \mathrm{CO}_{2}$ during Pennington time was estimated by Mora et al. (1996) as $600-1000 \mathrm{ppm} \mathrm{V}$, or $2-5 \times$ present atmospheric level, based on the $\delta^{13} \mathrm{C}$ values measured from Pennington Formation pedogenic calcite and using the carbonate palaeobarometer of Cerling (1991); these data indicate that the Early Carboniferous palaeoclimate in Tennessee was transitional between that of greenhouse (high $p \mathrm{CO}_{2}$ ) and icehouse (low $p \mathrm{CO}_{2}$ ) conditions.

Most vertic claystone paleosols previously identified in the Pennington Formation apparently formed from siliciclastic material, chiefly estuarine and floodplain clay and silt (Caudill et al., 1992, 1996; Driese et al., 2000; Robinson et al., 2000). Actualistic studies of a modern Vertisol chronosequence in Texas suggest that these siliciclastic (clay)-parented Pennington paleosols formed over time frames ranging from hundreds to perhaps a 
few thousand years (Robinson et al., 2000; Robinson, 2001). Soils that form on carbonate parent materials, in contrast, are composed of the residuum, either insoluble or undissolved material remaining from the dissolution of weathered carbonate rock, and the texture of the soil formed is dependent on the particle sizes of noncarbonate material present in the carbonate (Buol et al., 1997). However, a major problem with invoking carbonate rock weathering as a mechanism for formation of clay-rich soils occurring within limestone terrains is that it requires prolonged weathering and dissolution of a significant (or even unreasonable) thickness of bedrock in order to produce even a relatively thin soil mantle (e.g., Olson et al., 1980), depending on the percent of residuum.

In a previous study, Driese et al. (2000) compared the mass-balance geochemistry of a Pennington Formation claystone paleosol formed from marine and estuarine siliciclastic mudrocks with that of a Houston Black series Vertisol pedon formed on smectitic Cretaceous marine shales near Zabcikville, in Bell County, TX. Their study demonstrated that Paleozoic paleosols can retain a significant amount of their primary pedochemical patterns, in spite of burial diagenetic alteration, and that valid geochemical comparisons can be made between vertic paleosols and their modern Vertisol counterparts, thus further supporting the research approaches presented in this paper.

\section{Site locations and methodology}

\subsection{Pennington Formation paleosol}

The outcrop studied is a roadcut exposure located on US Highway 70 between Crossville and Sparta, TN (Fig. 1). At this locality, the contact between the Bangor Limestone and Pennington Formation (Upper Mississippian) is exposed, comprising $10 \mathrm{~m}$ of the upper Bangor Limestone and $25 \mathrm{~m}$ of the lower Pennington Formation (Figs. 2 and 3; Harding, 1995; Robinson, 2001). The outcrop section of paleosol exposed was $12 \mathrm{~m}$ long, and paleosol thickness varied from 30 to $65 \mathrm{~cm}$ (Fig. 3A). Description of paleosol field morphology was according to Retallack (1988). Colour was determined from dry samples

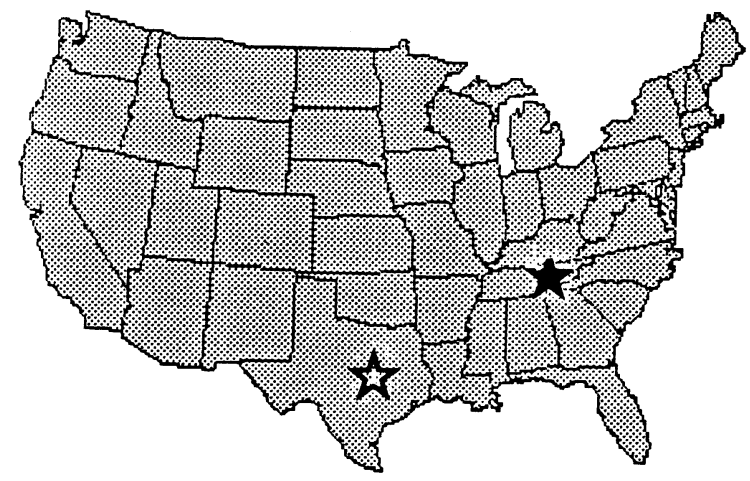

Fig. 1. Location of Pennington Formation outcrop near Sparta, TN (solid star), and Houston Black series soil pit near Riesel, TX (open star).

using the Munsell Rock Color Chart (1984). Four vertical profiles were sampled along the length of the exposed paleosol, including the underlying dolostone. Samples for bulk density and geochemical analysis were collected at $10 \mathrm{~cm}$ intervals throughout each paleosol profile, with a $5-\mathrm{cm}$ sampling interval at both the upper and lower contacts of the paleosol with bounding nonpedogenic strata. A red clayshale lacking pedogenic features was collected about $2 \mathrm{~m}$ beneath the paleosol for use as a proxy noncalcareous parent material. Samples prepared into thin sections were collected from Profile 1, the most complete and thickest paleosol section (Fig. 3B). Thin-section samples were coated with polyester boat-resin in the field, and were later impregnated with thinsection epoxy, due to their friable nature. Thin sections were prepared while dry using sandpaper as an abrasive in order to achieve proper thickness $(30 \mu \mathrm{m})$ as described in Mora et al. (1993). All thin sections were examined using standard petrographic techniques. The petrography of the paleosol was described using the terminology of Brewer (1976) and Fitzpatrick (1993). Bulk densities of the paleosol and subjacent dolostone were determined by the wax clod method (Blake and Hartge, 1986). The bulk geochemistry of the paleosol was determined using an EG\&G, ORTEC X-ray fluorescence (XRF) analyzer and pressed pellets made from 3 to $5 \mathrm{~g}$ of powdered sample. XRF analyses are reported as weight percent oxides and elements (Appendix B). Dolostone samples were dissolved in an aqua regia 


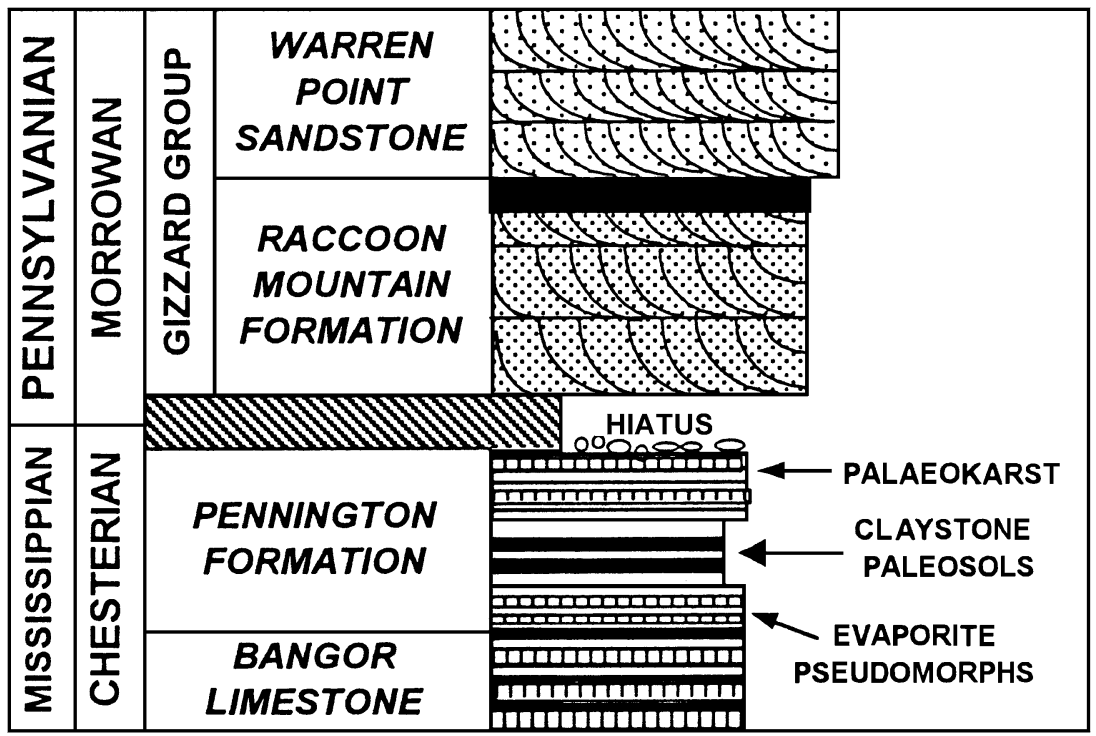

Fig. 2. Stratigraphic column depicting Bangor Limestone, Pennington Formation, Raccoon Mountain Formation, and Warren Point Sandstone in eastern Tennessee.

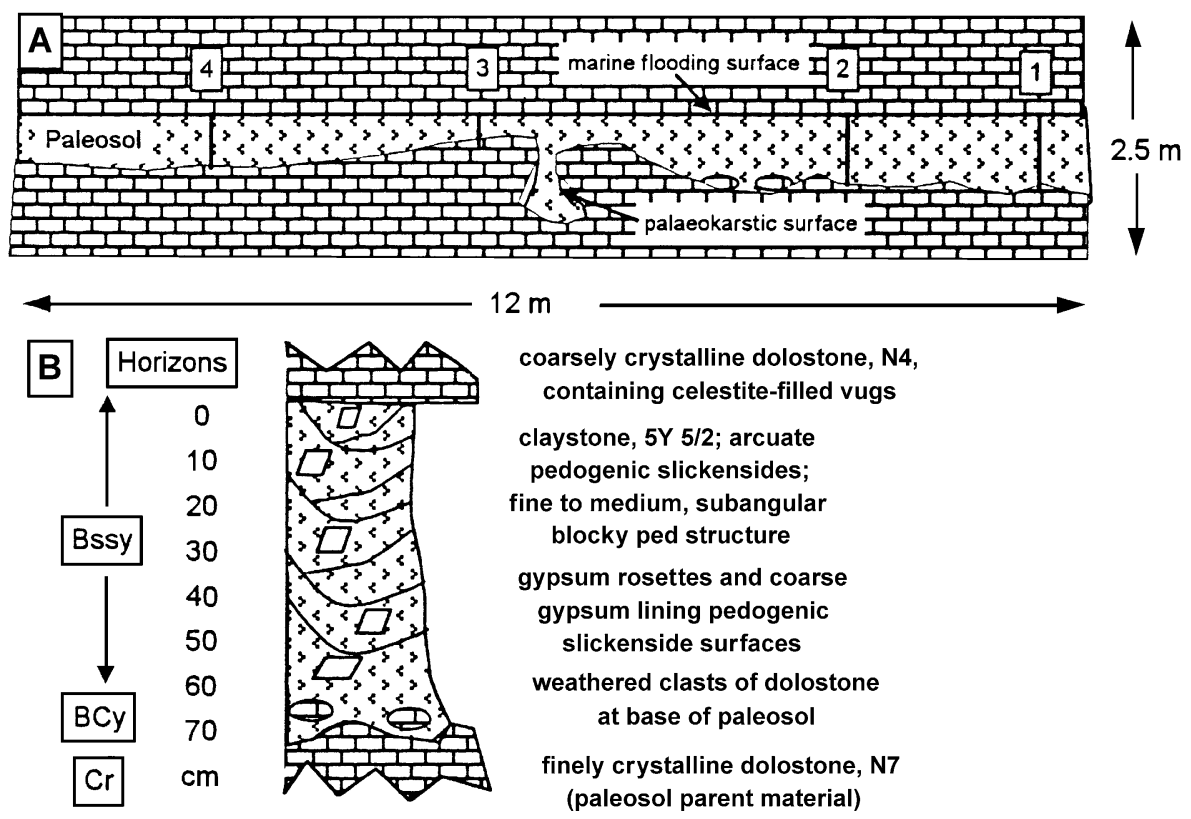

Fig. 3. (A) Field sketch of lower Pennington Formation outcrop showing grey-green siliciclastic paleosol, sub- and superjacent dolostone beds, and locations of sampling profiles 1-4. (B) Stratigraphic column of lower Pennington paleosol at Sparta, TN shown in sketch in (A). Note: Bss is accepted by USDA Soil Survey Staff as designation for B horizon dominated by pedogenic slickensides, and Bssy refers to slickensided B horizon containing gypsum. 
solution in order to determine insoluble residue content.

\subsection{Houston Black series Vertisol}

The modern analog site is a low relief, rolling terrain, presently in pasture grasses, which is dominated by Vertisols of the Houston Black series (Templin et al., 1956; Kunze and Templin, 1956). The Houston Black series consists of calcareous, dark-coloured, clayey soils with high shrink-swell potential, which form on Cretaceous marine clay and marl (Taylor Group), or on argillaceous limestone (Austin or Pecan Gap Chalk; Fig. 4) (see also the
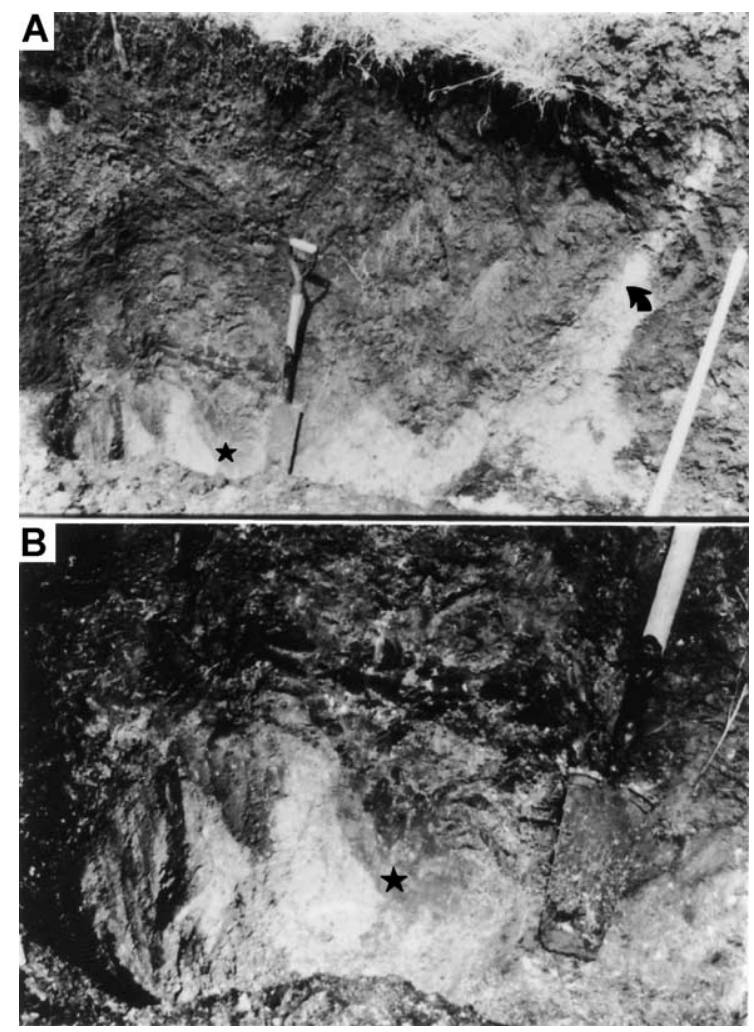

Fig. 4. Field photographs of modern Vertisol (Houston Black series) near Riesel, TX, taken in March 1998. (A) Gilgai microlow (shovel) with tongue of Cretaceous chalk parent material defining microhigh. Note undulating, scalloped contact between soil and underlying bedrock (star). Shovel measures $120 \mathrm{~cm}$ in length. (B) Scalloped contact between soil and underlying Cretaceous chalk, showing gradational boundary and weathering front (star) in chalk (BCk and Cr horizons in Appendix A). following website for a more general series description: http://www.statlab.iastate.edu/soils/). Soil microrelief (gilgai) consists of circular microhigh knolls, $10-60 \mathrm{~cm}$ above adjacent microlows, with spacings of 2-6 $\mathrm{m}$ between laterally adjacent microhighs and microlows (Fig. 4). When dry conditions prevail, the soil commonly cracks to depths of up to $1 \mathrm{~m}$. The site has a humid-subtropical climate characterized by hot, humid summers. The mean annual precipitation (86 $\mathrm{cm}$ ) is evenly distributed throughout the year, except during July and August, which are relatively dry months averaging only $5 \mathrm{~cm} /$ month (see the National Climatic Data Center website, based in Asheville, $\mathrm{NC}$, at http://lwf.ncdc.noaa.gov/oa/ncdc.html). Evaporation of surface water is estimated to be about 142 $\mathrm{cm} /$ year with an average frost-free period of 260 days.

In March 1998, a 2.5-m deep by $7 \mathrm{~m}$ long pit was excavated with a backhoe in a Houston Black series pedon, in McLennan County, near Riesel, TX (Figs. 1 and 4). At this site, the Houston Black soil is classified as a fine, smectitic, thermic, Udic Haplustert (Soil Survey Staff, 1998); horizonation and field morphology are described in Appendix A. The soil profile was measured and described using standard pedological techniques (Soil Survey Staff, 1998; Appendix A). Bulk soil samples were collected at $10-\mathrm{cm}$ intervals along vertical profiles through a gilgai microlow. Selected thin-section samples were collected from each of horizons described in the field. After manual removal of macroscale organic matter and oven drying at $60{ }^{\circ} \mathrm{C}$, pressed pellets were prepared from bulk, powdered soil samples and analyzed for selected major, minor and trace elements using an XRF analyzer, as described previously.

\subsection{Mass-balance geochemistry and carbonate cor- rection}

Whole-rock XRF chemical data were evaluated using a mass-balance approach, following Brimhall et al. (1988, 1991a,b). The mass-balance approach evaluates chemical variations in a soil due to: (1) the closed-system effects of residual enrichment and volumetric changes in the soil matrix, and (2) opensystem transport of material into or out of the soil. These values can be characterised without making a direct volume measurement; only element concentra- 
tion and bulk density measurements are necessary. Discussions of governing mass-balance equations are presented by Driese et al. (2000).

Because significant carbonate content can lower the composite sample weight, elemental weight percentages were corrected for carbonate content dilution prior to mass-balance calculations (modified from Soil Survey Staff, 1995). Carbonate correction factors (CCF) were determined from the following stepwise calculation.

(1) Background $\mathrm{CaO}$ wt. $\%$ was determined for each soil and paleosol as an average of $\mathrm{CaO}$ wt.\% in intervals within the depth of effective leaching. This value was then subtracted from $\mathrm{CaO}$ wt.\% for each depth interval of all profiles. Any difference $<0$ was assumed to have a CCF of 1.00 .

(2) $\mathrm{CaO}$ wt.\% was converted to $\mathrm{Ca}$ wt.\% by multiplying by 0.71 , and if the depth interval contained any sulfur (S), S wt.\% was subtracted from $\mathrm{Ca}$ wt. $\%$ to account for gypsum. The Ca wt. $\%$ difference was converted to carbonate equivalent wt.\% by multiplying by 1.50 .

(3) The final CCF was determined as $(100 \%+$ carbonate wt.\%)/100\%. All elements were then multiplied by the CCF to determine the corrected elemental values.

\section{Paleosol and soil description}

\subsection{Field relationships of lower Pennington paleosol}

The Pennington Formation paleosol is bounded above and below by marine carbonate units (Fig. 3). A finely crystalline, light grey (N7) argillaceous dolostone underlies the paleosol (Figs. 3 and 5), whereas the overlying carbonate is a coarsely crystalline, medium dark grey (N4) dolostone that contains celestite-, calcite-, and dolomite-filled vugs (determined by X-ray diffraction by Harding, 1995). The lower contact of the paleosol is undulatory and palaeokarstic, with some development of solution pipes and smallscale karren; in addition, weathered dolostone clasts are common within $5-10 \mathrm{~cm}$ of the lower contact (Figs. 3A and 5). The upper contact of the paleosol, in contrast, is erosive and knife-sharp, and is locally pyritised (Fig. 3). The paleosol exhibits highly variable thicknesses, ranging from 30 to $65+\mathrm{cm}$.
Fine to medium, angular to subangular blocky ped structure occurs throughout the paleosol, except for an uppermost layer exhibiting a fine, platy structure (Figs. 3B and 5). The thin, platy peds are yellowishgrey to olive grey in colour (5Y $7 / 2$ to $5 \mathrm{Y} \mathrm{3/2}$ ), whereas the majority of the paleosol tends to be light olive grey $(5 \mathrm{Y} 5 / 2)$. A Bssy horizon is the dominant type, characterised by arcuate, pedogenic slickensides with polished, striated surfaces, and with the slickensides intersecting to form wedge-shaped peds. Slickensides converge at $1-1.5 \mathrm{~m}$ spaced intervals to form pseudoanticlines. Few obvious root traces are present. Iron staining, probably related to pyrite oxidation, manifests as a dark yellowish orange color (10YR 6/ 6) that commonly follows slickenside planes. Gypsum rosettes are also present within the paleosol matrix in the Bssy horizon, and coarse gypsum bands are also common along slickenside planes (Figs. 3B and 5).

\subsection{Petrography of lower Pennington paleosol}

The claystone matrix of the paleosol exhibits one dominant direction of birefringent clay orientation, although a second direction of clay orientation, orthogonal to the first but not as well defined, is also present (Fig. 6A,B); this characteristic sepic-plasmic fabric (Brewer, 1976) is commonly reported in vertic claystone paleosols (e.g., Driese and Foreman, 1992; Driese et al., 1992; Mora and Driese, 1999). Iron staining in the paleosol consists of dark orange concentrations of $\mathrm{Fe}$ and/or Mn outlining peds and comprising $\mathrm{Fe} / \mathrm{Mn}$ glaebules and nodules (Fig. 6C). Other $\mathrm{Fe}$ occurrences include framboidal pyrite and siderite (oxidised pyrite) crystals (Fig. 6C,D). Stress cutans, defined by birefringent clays, also outline peds. Gypsum occurs as lenticular and columnar bands, as well as aggregates of fine crystal rosettes. The paleosol claystone matrix contains $1-5 \%$ silt, which is mainly quartz and K-feldspar. No pedogenic carbonate was observed in the paleosol.

Thin sections sampled at or near the contact with the subjacent dolostone show weathered rinds on the dolostone, as well as weathered clasts derived from the dolostone floating in the paleosol matrix (Fig. $6 \mathrm{E}-\mathrm{G}$; cf. Fig. 5). Paleosol matrix material has infiltrated into the fractures in the underlying dolostone, and some resembles illuviated clay with a 

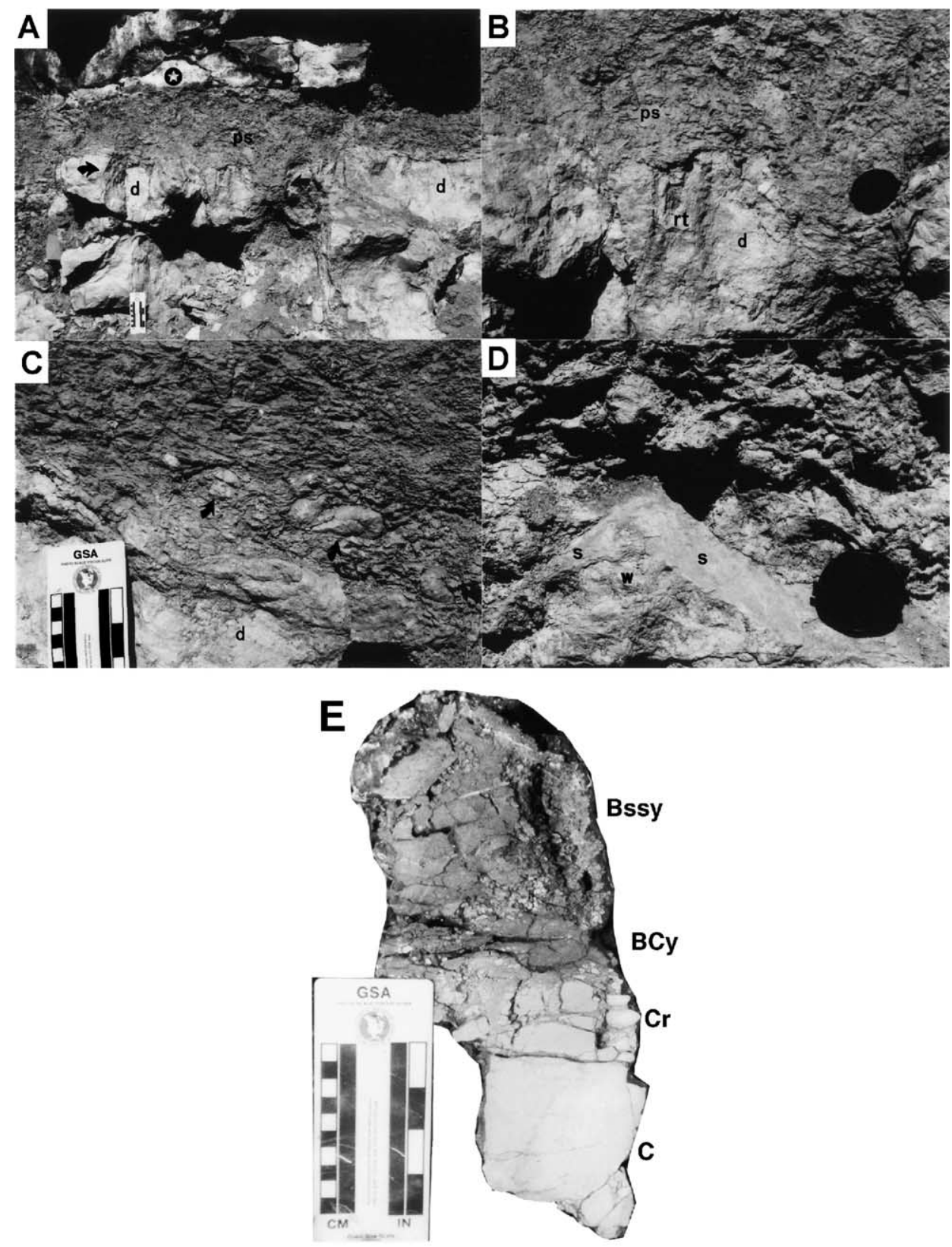

Fig. 5. Outcrop photographs of Lower Pennington Formation paleosol near Sparta, Tennessee. (A) Paleosol (ps) overlying dolostone (d) exhibiting palaeokarst-related dissolution pipes (arrows), and sharply overlain by marine dolostone (star). (B) Close-up of karstic dissolution pipe infilled with paleosol claystone (lens cap), with root traces (rt) extending downward from paleosol (ps) into dolostone (d). (C) Contact between dolostone (d) and paleosol showing weathered clasts (arrows) of dolostone floating in paleosol claystone. (D) Pedogenic slickensides (s) bounding wedge-shaped structural aggregate (w) in paleosol claystone. (E) Slabbed hand sample from Profile 1 (Fig. 3B), showing undulatory, transitional nature of lower contact with dolostone ( $\mathrm{Cr}$ horizon), weathered dolostone clasts in the lower portion of the paleosol (BCy horizon), and fine to medium, angular blocky ped structure of paleosol (Bssy horizon). Horizon assignments are shown on right. Scale card is $15 \mathrm{~cm}$, lens cap is $5.5 \mathrm{~cm}$ in diameter. 

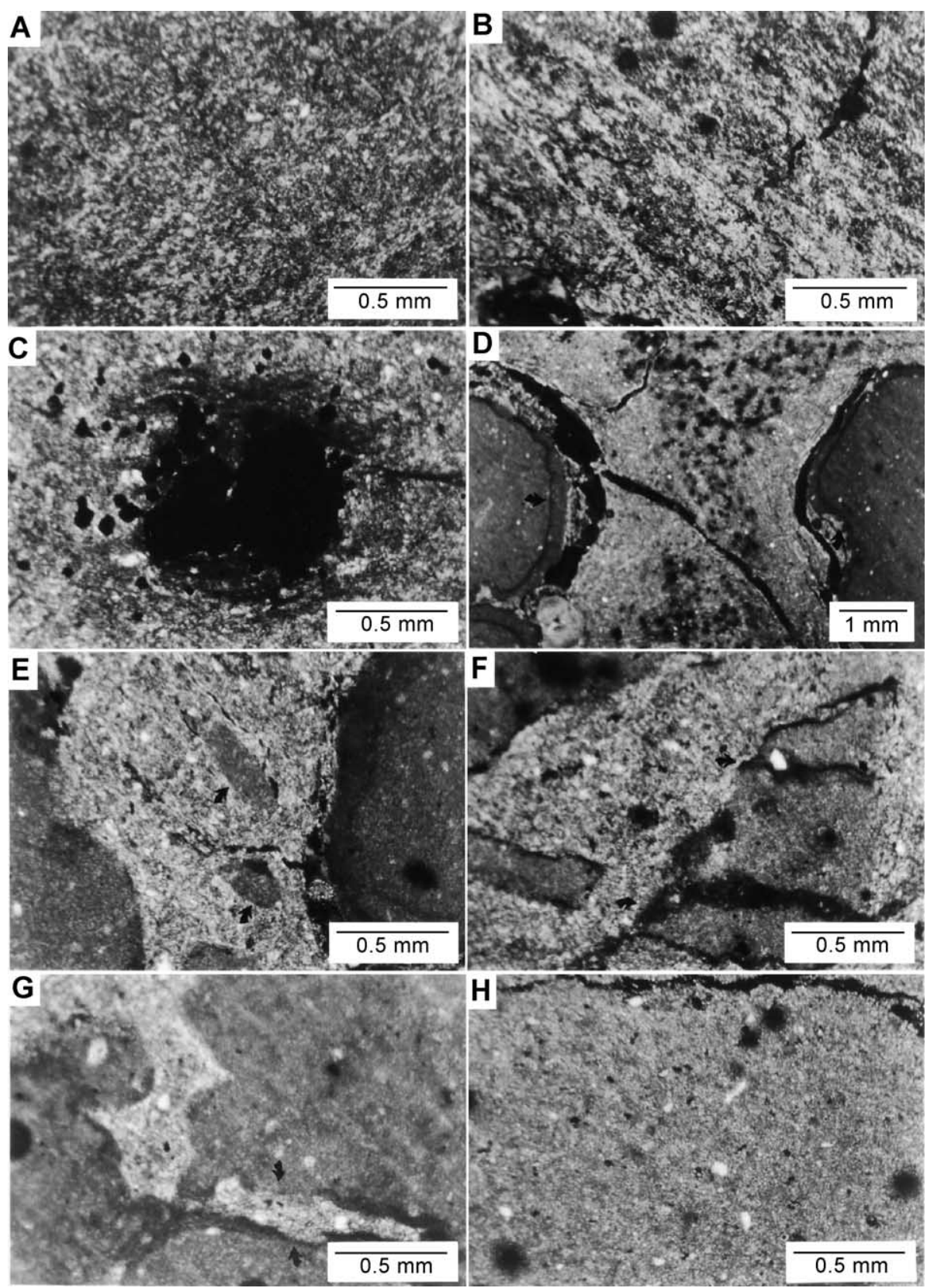

Fig. 6. Photomicrographs of Pennington paleosol from Profile 1. All photos are in crossed-polarised light. (A) Sepic-plasmic fabric of paleosol showing two flecked clay orientations (sepic-plasmic fabric), $10 \mathrm{~cm}$ depth. (B) Sepic-plasmic fabric of paleosol showing flecked clay orientations with one primary direction of oriented clays, $40 \mathrm{~cm}$ depth. (C) Fe and/or Mn concentrations forming diffuse glaebule in paleosol matrix, $30 \mathrm{~cm}$ depth. (D) Pyrite and siderite (?) crystals floating in paleosol matrix in interstitial area of weathered dolostone, which shows weathering rinds (arrows), $60 \mathrm{~cm}$ depth. (E) Weathered dolostone clasts engulfed in paleosol matrix at lower contact, $60 \mathrm{~cm}$ depth. (F) Weathered dolostone clasts with dark rinds and layers (arrows) at lower contact, $55 \mathrm{~cm}$ depth. (G) Illuviated clay infilling a possible root trace in weathered dolostone, $60 \mathrm{~cm}$ depth. (H) Subjacent dolostone showing fine-grained dolomite crystals in a micritic matrix, along with quartz silt grains, $100 \mathrm{~cm}$ depth. 
strong birefringence fabric (Fig. 6G) (Fitzpatrick, 1993). The contact between paleosol and dolostone is gradational and consists of paleosol claystone matrix engulfing dolostone clasts that are weathered to varying degrees, grading downward into progressively less-weathered dolostone.

The subjacent and superjacent carbonate rocks vary greatly with respect to their petrology. The subjacent dolostone (Fig. 6H) is very finely crystalline, appears very muddy or "dirty", and is composed of fine-grained dolomite crystals floating in a largely micritic matrix that contains small amounts of quartz and feldspar silt. The subjacent dolostone has a relatively high insoluble residue content of $28 \%$, which consists of about $98 \%$ clay and $2 \%$ silt (chiefly quartz), but which also includes pyrite and/or siderite crystals. The superjacent dolostone is much more coarsely crystalline, and is primarily composed of euhedral dolomite crystals cemented by dolomite microspar.

\subsection{Macromorphology of Houston Black Vertisol}

The Houston Black series pedon from Riesel, TX, rests directly on Cretaceous Pecan Gap Chalk (Fig. 4; Appendix A). The contact between the lightcoloured chalk and the dark-coloured soil matrix ranges from gradational to sharp and is scalloped or fluted, exhibiting numerous chalk pinnacles with local relief up to $30-50 \mathrm{~cm}$ (Fig. 4B). Chalk occurs at greatest depth $(>200 \mathrm{~cm})$ within gilgai microlows. Some B horizon material containing weathered chalk lithoclasts has been entrained along master slickensides and thrust upward into the cores of gilgai microhighs, forming chimney-like "tongues" of light-coloured soil that extend almost to the soil surface (Fig. 4A).

Pedogenic slickensides first appear at about $34 \mathrm{~cm}$ depth (Bss1 horizon) and become more closely spaced and higher angle between 67 and $107 \mathrm{~cm}$ (Bss2 horizon). Subangular to angular blocky ped structures are well developed in all of the Bss horizons, and many peds have polished pressure faces. Pedogenic carbonate begins at a depth of $139 \mathrm{~cm}$ in the Bssk horizon, mainly as $1-3 \mathrm{~cm}$ diameter powdery calcite masses that commonly contain hard calcite cores. At $189 \mathrm{~cm}$ depth (BCk horizon), some fragments of weathered chalk occur floating within the soil matrix, and weath- ered bedrock (Cr horizon) occurs at a depth of $212 \mathrm{~cm}$. Medium- to coarse sand-sized quartz, quartz granules, and small vein quartz pebbles, up to $2 \mathrm{~cm}$ in diameter, occur throughout the soil profile, but in amounts never exceeding $1 \%$. No coarse quartz grains or pebbles were observed in the underlying chalk.

\subsection{Micromorphology of Houston Black Vertisol}

Sepic-plasmic fabrics characterised by oriented birefringent clays dominate the fine soil matrix in the Houston Black soil, as was the case for the Pennington Formation paleosol. However, unlike the Pennington paleosol, pedogenic carbonate is abundant in the Houston Black soil, and includes both hard calcite nodules recrystallised to microspar and powdery calcite masses (Fig. 7A,B). Fragments of chalk occur throughout the soil, and include easily recognisable foraminifera coated by pedogenic carbonate, and foraminiferal fragments containing unaltered internal calcite and sphaerosiderite cement pore-fillings (Fig. 7C,D). The contact between soil and weathered bedrock is generally gradational, even at the thin-section scale (Fig. 7E,F), although erosionally truncated microfossils are also visible along some microkarstic surfaces (Fig. 7G). The chalk is generally a foraminiferal wackestone that contains $75 \%$ micrite, $20 \%$ foraminifera with internal calcite and sphaerosiderite cement pore-fillings, and about 5\% detrital quartz and feldspar silt, with rare glauconite silt grains (Fig. $7 \mathrm{H}$ ). Fe/Mn glaebules and concretions, generally $<1 \mathrm{~mm}$ in diameter, are locally abundant within the soil matrix.

Medium- to coarse sand-sized monocrystalline quartz, some of which exhibits abraded quartz overgrowths, as well as coarser vein quartz granules and pebbles, are also present in low concentrations. These grains clearly do not appear to have been derived from the underlying Cretaceous chalk, and require consideration of another (secondary?) source of detrital material during pedogenesis (Fig. 8).

\subsection{Mass-balance geochemistry}

\subsubsection{Parent material uniformity and determination of immobile index element}

Parent material uniformity and determination of immobile index element were assessed using $\mathrm{Zr}$ vs. 


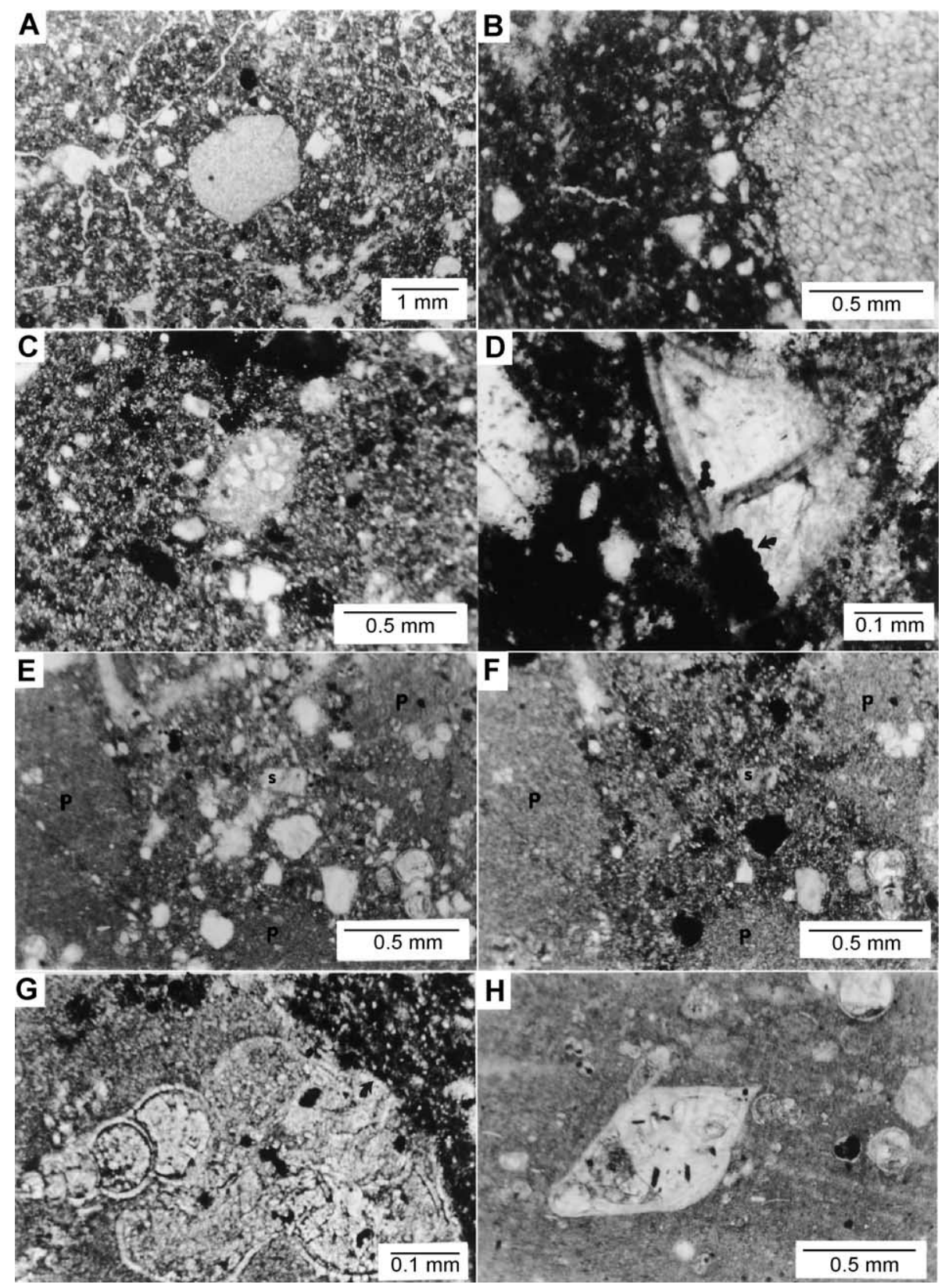

Fig. 7. Photomicrographs of modern Vertisol (Houston Black series) from Riesel, TX. (C) and (F) are in crossed-polarised light; all other photos are plane-polarized light. (A) Hard pedogenic carbonate nodule recrystallized to microspar. A2 horizon, $13-34 \mathrm{~cm}$ depth, microlow pedon. (B) Hard pedogenic carbonate nodule recrystallized to microspar. Bssk horizon, $139-189 \mathrm{~cm}$ depth, microlow pedon. (C) Foraminifera fragment (center) derived from Cretaceous chalk parent material engulfed by pedogenic carbonate. A2 horizon, $13-34 \mathrm{~cm}$ depth, microlow pedon. (D) Foraminifera fragment (center) derived from Cretaceous chalk parent material, with original diagenetic calcite pore-filling containing fine sphaerosiderite crystals (arrow), all engulfed within soil matrix. Bssk horizon, 139-189 cm depth, microlow pedon. (E,F) Irregular, diffuse contact between soil matrix (s) and Cretaceous chalk parent material (p) containing foraminfera. BCk and Cr horizon contacts, depth about 212 $\mathrm{cm}$, microlow pedon. $(\mathrm{G})$ Marine foraminifer in Cretaceous chalk parent material erosionally truncated adjacent to soil matrix (arrow). BCk and Cr horizon contacts, depth about $212 \mathrm{~cm}$, microlow pedon. (H) Cretaceous chalk (foraminiferal wackestone) parent material for Houston Black series Vertisol. Cr horizon, depth about $230 \mathrm{~cm}$. 

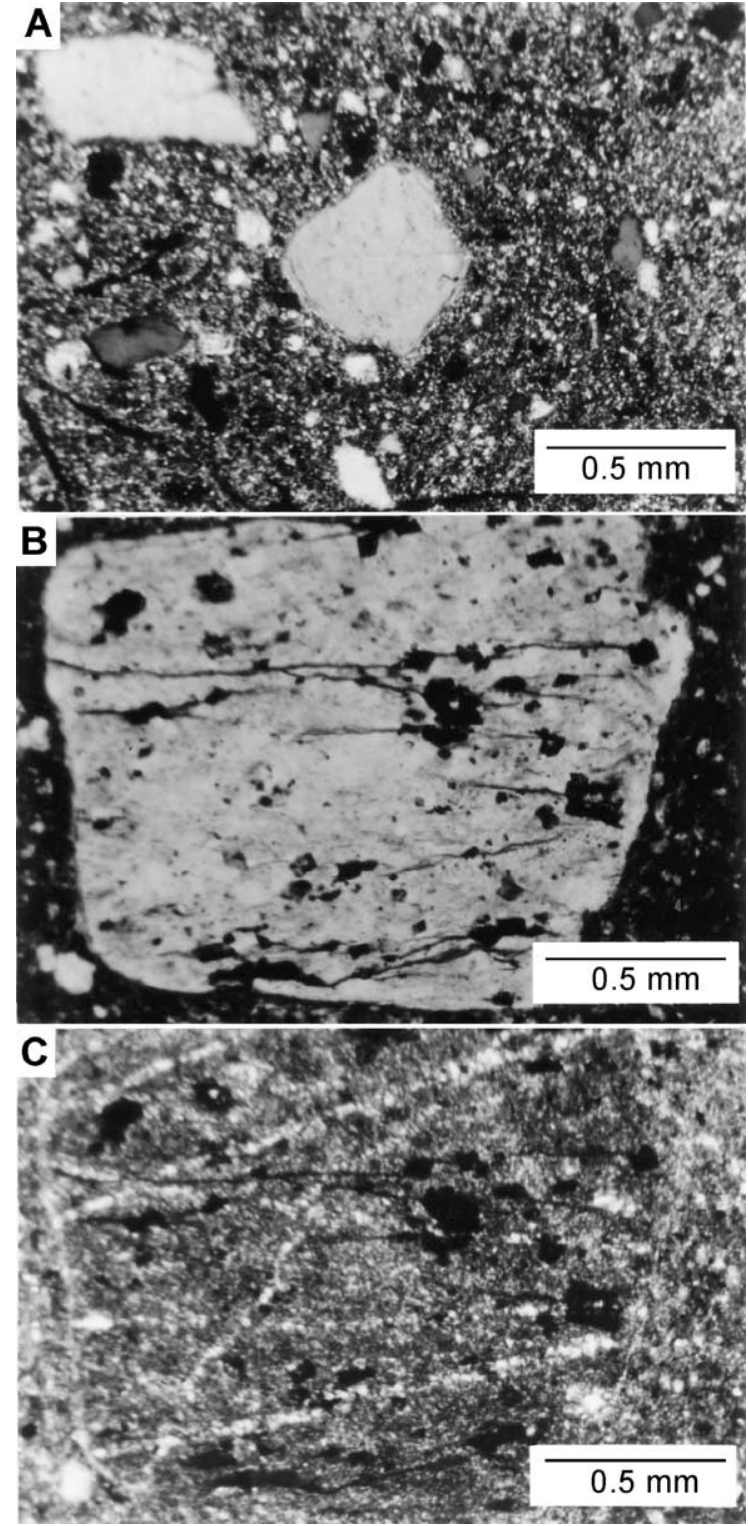

Fig. 8. Examples of sediment grains in modern Vertisol probably not derived from underlying Cretaceous chalk parent material. (A) and (C) are under crossed nicols; (B) is in plane-polarised light. (A) Medium sand-sized monocrystalline quartz grain (center) with abraded quartz overgrowth recycled from sandstone deposits. Bss2 horizon, depth $=67-107 \mathrm{~cm}$. (B, C) Coarse sand-sized, highly fractured chert grain derived from sandstone or gravel deposits. Bss2 horizon.

$\mathrm{Zr} / \mathrm{TiO}_{2}$ and $\mathrm{TiO}_{2}$ vs. $\mathrm{TiO}_{2} / \mathrm{Zr}$ cross-plots, as well as plots of $\mathrm{Zr} / \mathrm{TiO}_{2}$ and $\mathrm{TiO}_{2} / \mathrm{Zr}$ vs. depth (Fig. 9; cf. Ashley and Driese, 2000; Driese et al., 2000). These data were then compared with data compiled by Stiles (2001) for alluvial clay-parented modern Vertisols in the Coast Prairie of Texas. The Houston Black pedon examined in our study contains somewhat less $\mathrm{Zr}$, but essentially similar $\mathrm{TiO}_{2}$, as the Texas soils analyzed by Stiles (2001) (Fig. 9A,B). The Cretaceous chalk beneath the Houston Black pedon contains only about $14 \%$ of the $\mathrm{Zr}$ and $30 \%$ of the $\mathrm{TiO}_{2}$ contained in the overlying soil, and there is a pronounced shift in both $\mathrm{Zr} / \mathrm{TiO}_{2}$ and the $\mathrm{TiO}_{2} / \mathrm{Zr}$ at a depth of $180 \mathrm{~cm}$, which corresponds to the Bssk/BCk horizon boundaries (Fig. 9C,D). These relationships are best explained by the influx of detrital silt carrying zircon grains into the Houston Black soil profile, with downward translocation of these grains to the average depth of soil cracking and shrink-swell processes.

The two Pennington paleosol profiles examined in our study contain generally less $\mathrm{Zr}$, and much greater $\mathrm{TiO}_{2}$, than either the Houston black soil or the Texas soils analyzed by Stiles (2001) (Fig. 9A,B). The marine dolostone beneath the two Pennington paleosol sample profiles contains only about $20-25 \%$ of the $\mathrm{Zr}$ and $10-15 \%$ of the $\mathrm{TiO}_{2}$ contained in the overlying paleosol, and there is a pronounced shift in both $\mathrm{Zr}$ / $\mathrm{TiO}_{2}$ and the $\mathrm{TiO}_{2} / \mathrm{Zr}$ at the depth corresponding to the dolostone/paleosol contact, which corresponds to the Bssy/BCy horizon boundaries (Fig. 9C,D). These relationships are best explained by rejecting the hypothesis that the dolostone is the primary parent material for the paleosol, and instead considering an alternative hypothesis that the parent material was siliciclastic clay-rich material deposited on top of the dolostone prior to pedogenesis. A red clayshale that occurs about $2 \mathrm{~m}$ beneath the Pennington paleosol was considered as a proxy parent material, and contains both $\mathrm{Zr}$ and $\mathrm{TiO}_{2}$ concentrations that are comparable to those of the two Pennington paleosol profiles (Fig. 9). Previous research on both modern and ancient Vertisols (Driese et al., 2000; Robinson, 2001; Stiles, 2001) indicated that $\mathrm{Ti}$ is a more appropriate choice of immobile index element, mainly because many of the profiles show evidence for detrital (eolian?) influx of silt-sized zircon grains and their subsequent translocation within the profiles; however, in what follows we present strain (volume change) calculations, both corrected and uncorrected for carbonate dilution, and assuming either immobile $\mathrm{Ti}$ or $\mathrm{Zr}$, in order that the different results can be compared. We also show 

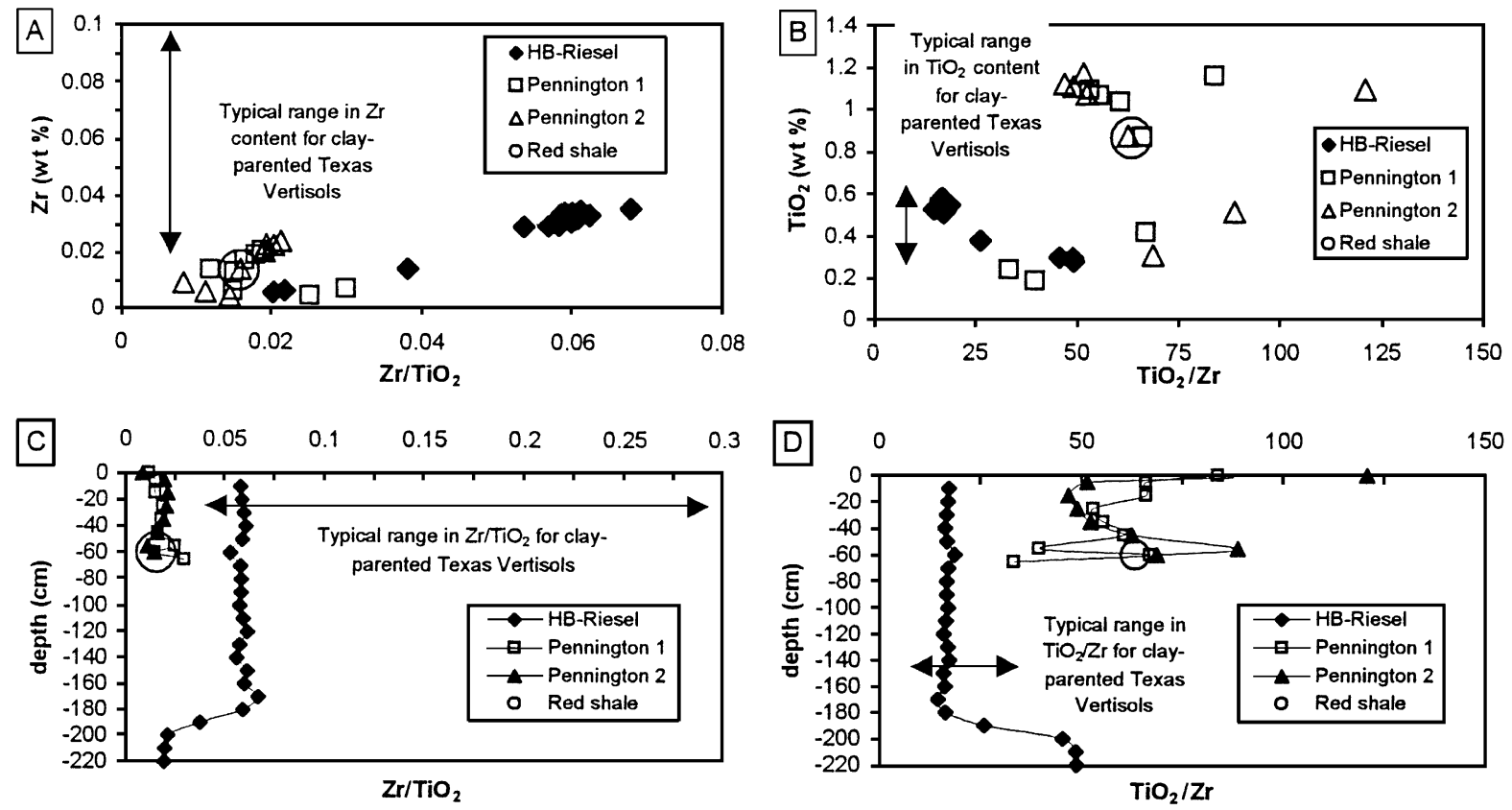

Fig. 9. $\mathrm{TiO}_{2}$ and $\mathrm{Zr}$ geochemistry of Pennington paleosol (Profiles 1and 2) and Houston Black series modern Vertisol formed on top of carbonate rocks. See text for discussion. (A) $\mathrm{Zr}$ vs. $\mathrm{Zr} / \mathrm{TiO}_{2}$ crossplot. (B) $\mathrm{TiO}_{2}$ vs. $\mathrm{TiO}_{2} / \mathrm{Zr}$ crossplot. (C) $\mathrm{Zr} / \mathrm{TiO}_{2}$ vs. depth crossplot. (D) TiO $2 / \mathrm{Zr}$ vs. depth crossplot. Hypothesized carbonate parent materials always exhibit lowest $\mathrm{Zr}$ and $\mathrm{TiO}_{2}$ contents. Large circle shows $\mathrm{Zr}$ and $\mathrm{TiO}{ }_{2}$ contents and ratios for hypothesized red clayshale proxy parent material. Ranges (double arrows) of $\mathrm{Zr}$ and $\mathrm{TiO}_{2}$ contents and ratios from clay alluviumparented Texas Vertisols are derived from Robinson (2001) and Stiles (2001).

calculations assuming either dolostone or red clayshale as the paleosol parent material.

\subsubsection{Modern Vertisol}

The upper $180 \mathrm{~cm}$ of the Houston Black pedon shows evidence for negative strain, or net soil volume loss, whereas the lower $20-30 \mathrm{~cm}$ has experienced positive strain, or net soil volume gain (Fig. 10A). Greater volume loss $(75-80 \%)$ is calculated assuming immobile $\mathrm{Zr}$ as compared with volume losses assuming immobile $\mathrm{TiO}_{2}$ (50\%). Calculations made after correction for carbonate dilution indicate slightly lower volume losses for each respective immobile index element (Fig. 10A).

The upper portion of the Houston Black pedon (to a depth of $180 \mathrm{~cm}$ ) is characterised by net removal of $80 \% \mathrm{Na}, 50 \% \mathrm{~K}$, and $25 \% \mathrm{Al}$, whereas $\mathrm{Si}$ shows a modest net gain of $5-10 \%$ (Fig. 10B). Inflections in the transport functions of these elements are noted at, and below, the interface of the lowest calcic horizon (BCk) and the Cr horizon. The elements S (90\% loss), $\mathrm{Ca}(80 \%$ loss $), \mathrm{Mg}$ (75\% loss), P (25\% loss), and $\mathrm{Sr}$
( $98 \%$ loss) exhibit similar behavior, with net decreases in the upper $180 \mathrm{~cm}$ of the soil, respectively (Fig. 10C,D). The redox sensitive elements $\mathrm{Fe}, \mathrm{Mn}, \mathrm{Cu}$ and $\mathrm{Cr}$ exhibit more complex transport functions (Fig. $10 \mathrm{D}, \mathrm{E} ; \mathrm{Ba}$ covaries with $\mathrm{Mn}$ and is also plotted). There is significant removal of $30 \%$ Fe from all but the lowest portions of the pedon, and more complex patterns of net positive gains in Mn $(200 \%)$, Ba (300\%), $\mathrm{Cu}(300 \%)$ and $\mathrm{Cr}(250 \%)$, which show strong covariation. The losses of other redox-sensitive trace elements such as Co (45\%) and As (5-10\%) (Fig. 10F), and of $\mathrm{V}, \mathrm{Ni}$ and $\mathrm{Pb}$ (not shown), generally mirrors that of $\mathrm{Fe}$. The large net gains $(50-75 \%)$ of the large ion lithophile element $\mathrm{Rb}$ (Fig. 10F) follows that of $\mathrm{Zr}, \mathrm{Mn}, \mathrm{Ba}, \mathrm{Cu}$ and $\mathrm{Cr}$, with net additions throughout the entire pedon.

\subsubsection{Pennington paleosol}

We used the mass-balance method to test two different hypotheses in determining the strain (volume change) and the translocations (net gains and losses) of elements in the paleosol. The hypotheses 

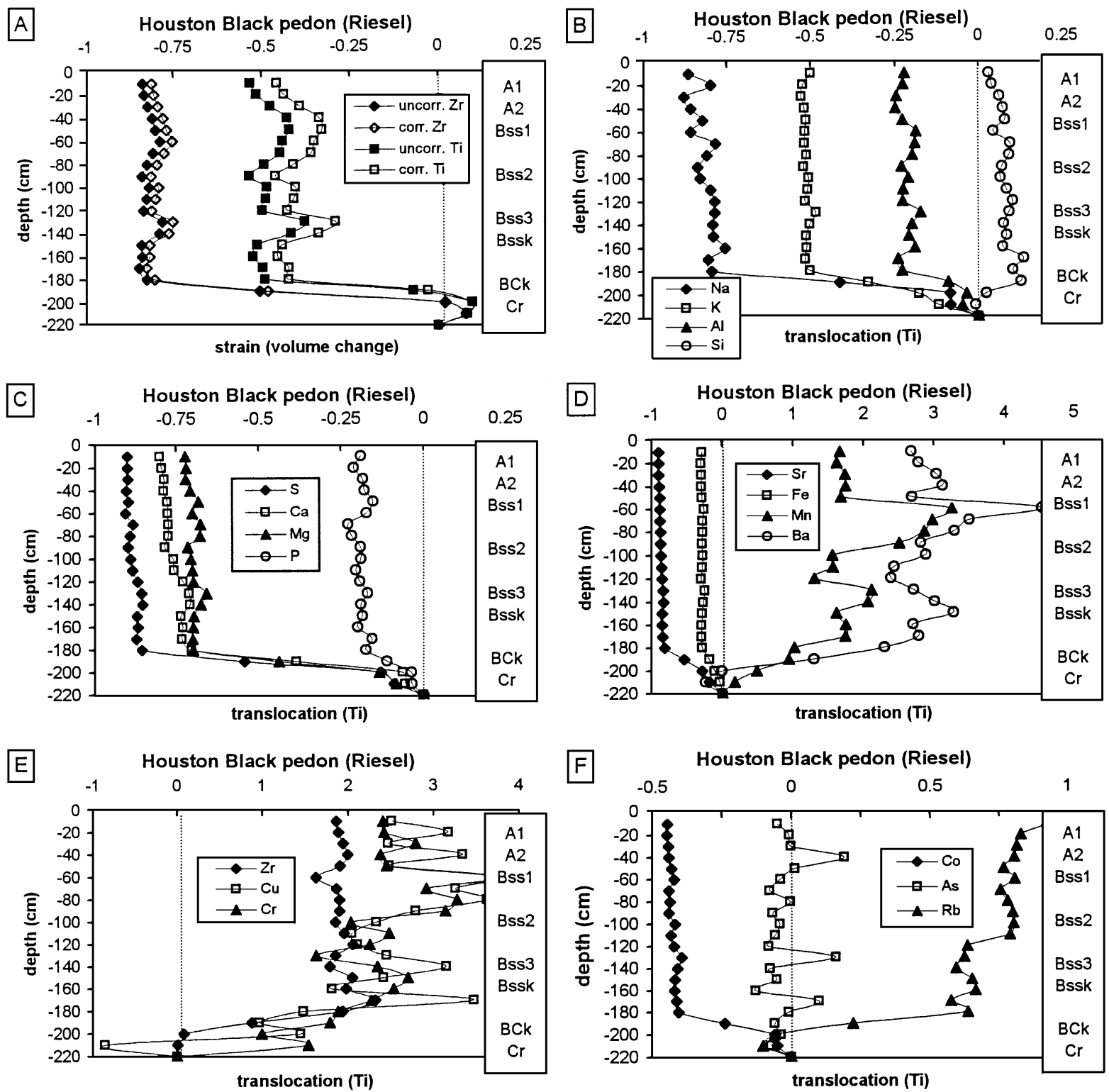

Fig. 10. Comparison of mass-balance reconstruction patterns of strain $(A, B)$ and element translocations $(C-H)$ for the Houston Black series modern Vertisol, assuming the subjacent Cretaceous chalk as the parent, versus depth in profiles. Element translocations all assume immobile Ti during pedogenesis. To convert to percentage increases in decreases, multiply values $\times 100$. Horizon designations are shown to right of each crossplot. See text for discussion. (A) Strain (volume change during weathering) calculated for modern Vertisol assuming either immobile Ti or immobile $\mathrm{Zr}$ during weathering, using both initial wt.\% and wt.\% corrected for carbonate dilution, as described in the text. (B) Translocations of $\mathrm{Na}, \mathrm{K}, \mathrm{Al}$, and Si. (C) Translocations of S, Ca, Mg, and P. (D) Translocations of Sr, Fe, Mn, and Ba. (E) Translocations of Zr, Cu, and Cr. (F) Translocations of $\mathrm{Co}$, As, and $\mathrm{Rb}$.

were: (1) that the dolostone directly beneath the paleosol was the parent, or (2) that nonpedogenic red clayshale chemically similar to that lying about 2 $\mathrm{m}$ beneath the paleosol was the parent material. These two hypotheses yielded somewhat different results for strain and translocations. 
The upper $40-50 \mathrm{~cm}$ of the paleosol shows evidence for negative strain, or net soil volume loss, due to translocation of mobile chemical constituents, whereas

A

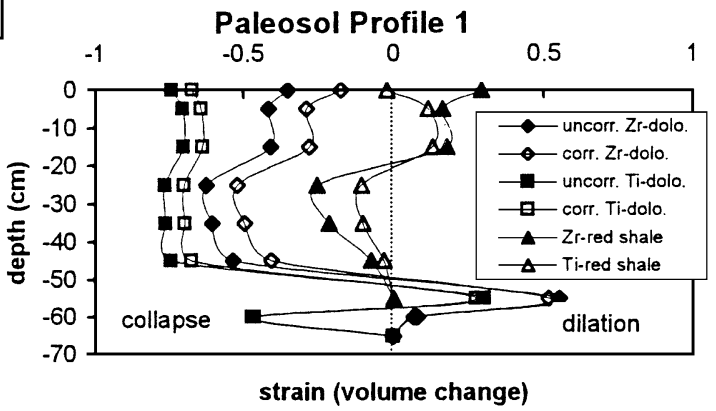

C

Paleosol Profile 2

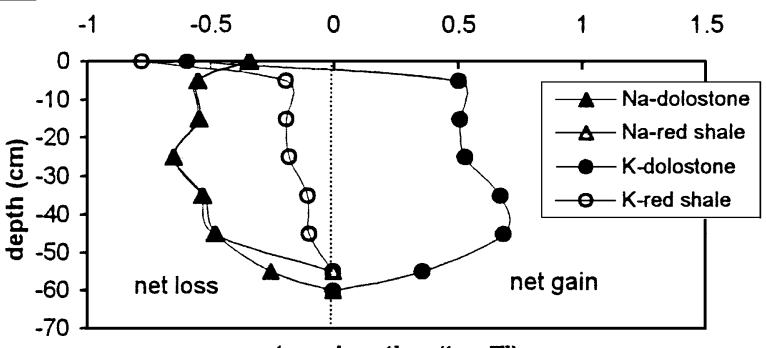

translocation (tau Ti)

E
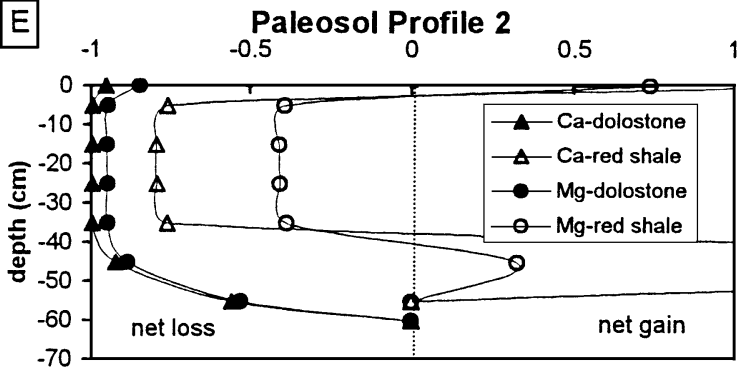

translocation (tau Ti)

G

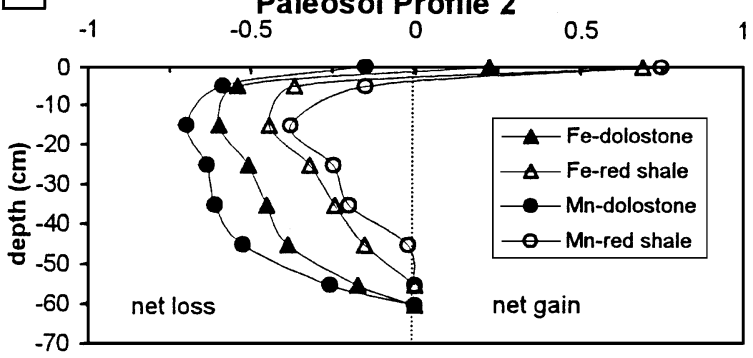

translocation (tau $\mathrm{Ti}$ ) the lower $10-20 \mathrm{~cm}$ has experienced positive strain, or net soil volume gain, probably due to displacive crystallisation of pedogenic calcite and gypsum (Fig.

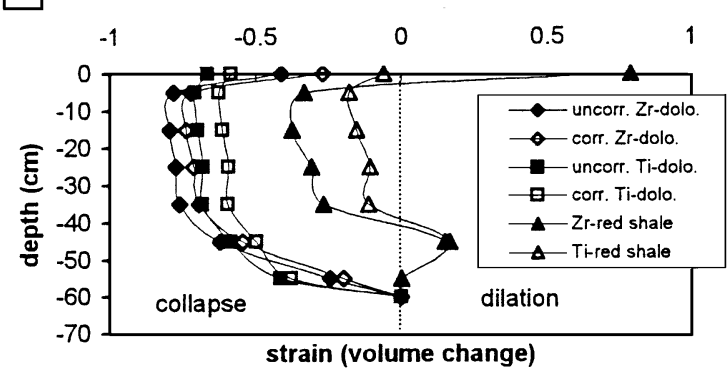

D

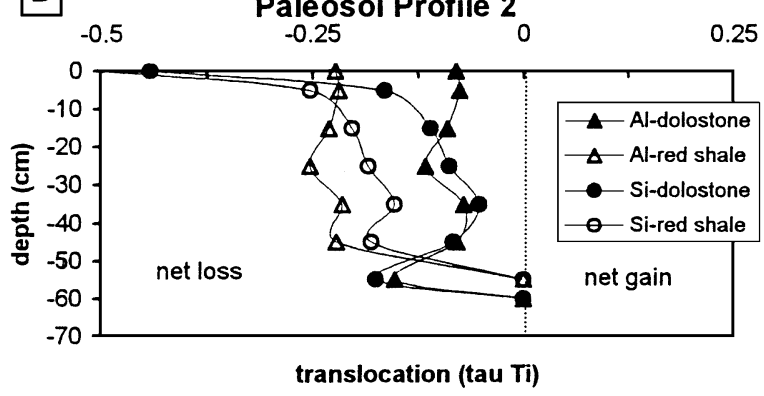

$\mathrm{F}$ Paleosol Profile 2

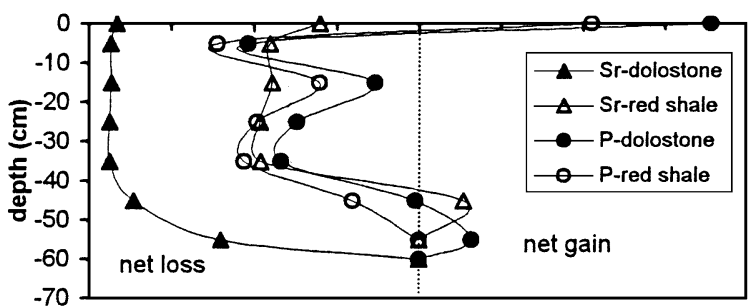

translocation (tau Ti)

$\mathrm{H}$

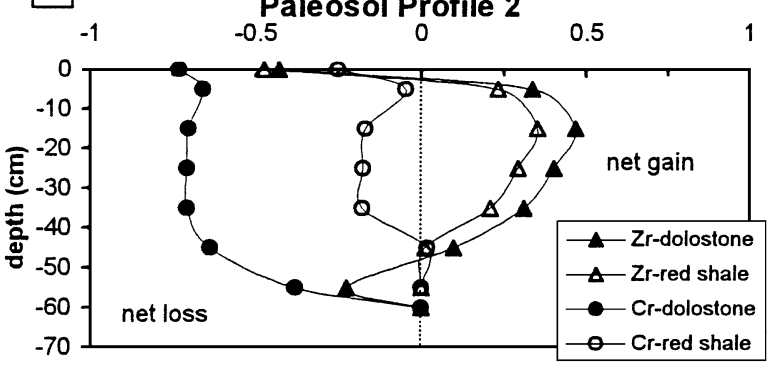

translocation (tau Ti) 
$11 \mathrm{~A}, \mathrm{~B})$. In profile 1 , greater volume loss $(75-80 \%)$ is calculated assuming immobile $\mathrm{TiO}_{2}$ as compared with volume losses assuming immobile $\mathrm{Zr}(40-50 \%)$ (Fig. $11 \mathrm{~A})$. In contrast, in profile 2 the two immobile indices yield similar strain estimates (Fig. 11B). Calculations assuming a noncalcareous, red clayshale parent material provide significantly lower strain estimates of $10-$ $30 \%$ volume loss, with some indications of dilation in the upper $20 \mathrm{~cm}$ of profile 1 and at $50 \mathrm{~cm}$ depth in profile 2; the dilations appear to correspond with especially gypsiferous parts of the paleosol. Calculations made after correction for carbonate dilution indicate slightly lower volume losses for each respective immobile index element (Fig. 11A,B).

For assumption 1, in which the deepest subjacent dolostone for each individual profile was assumed to be the parent material of the translocations for most of the alkali and alkaline earth elements exhibit a net loss (e.g., $50 \% \mathrm{Na} ; 95-99 \% \mathrm{Ca}, \mathrm{Mg}$, and $\mathrm{Sr}$ ) (compare Figs. 10B,C,D and 11C,E,F, respectively). Potassium $(\mathrm{K})$, in contrast to the other alkali and alkaline earth elements, shows a $50 \%$ net gain (Fig. 11C). Both Si and $\mathrm{Al}$ exhibit losses calculated between $10 \%$ and $15 \%$ (Fig. 11D). Phosphorus (P) losses of $25-50 \%$ are typical throughout most of the paleosol and resemble losses in the modern Vertisol (compare Figs. $10 \mathrm{C}$ and 11F). Net losses of redox-sensitive elements in the paleosol, including $50 \% \mathrm{Fe}, 60-75 \% \mathrm{Mn}$, and $75 \% \mathrm{Cr}$ (Fig. 11G,H), and similar losses of $\mathrm{Cu}, \mathrm{Co}, \mathrm{V}$, $\mathrm{Ni}$, and $\mathrm{Pb}$ (not shown), are typical. Many elements, such as P (Fig. 11F), Fe (Fig. 11G), and S, Cu, Co, V, and $\mathrm{Ni}$, are extremely elevated at the very top of the paleosol in contact with the overlying marine dolostone. Zirconium ( $\mathrm{Zr}$ ) is also enriched by up to $50 \%$ at the top of the paleosol (Fig. 11H).

For assumption 2, in which a noncalcareous, nonpedogenic red clayshale was assumed to be the parent material, the translocations for most of the alkali and alkaline earth elements exhibit net losses (e.g., 50\% $\mathrm{Na} ; 75 \% \mathrm{Ca}, 40-50 \% \mathrm{Mg}$ and $\mathrm{Sr}$ ) that are of lesser magnitude than those calculated for the dolostone parent material (Fig. 11C,E,F). Potassium (K) shows a $10-20 \%$ net loss, a pattern similar to the other alkali and alkaline earth elements (Fig. 11C). Both Si and Al exhibit losses $(20-25 \%)$ slightly greater than those calculated for the dolostone parent material (Fig. 11D). Phosphorus (P) losses of $25-50 \%$ are nearly identical to those calculated for the dolostone parent material (Fig. 11F). Net losses of redox-sensitive elements in the paleosol, including $10-40 \% \mathrm{Fe}$, $10-30 \% \mathrm{Mn}$, and $10-20 \% \mathrm{Cr}$ are lower than those calculated for the dolostone parent material (Fig. $11 \mathrm{G}, \mathrm{H})$. Many elements, such as P (Fig. 11F), Fe (Fig. $11 \mathrm{G}$ ), and $\mathrm{S}, \mathrm{Cu}, \mathrm{Co}, \mathrm{V}$, and $\mathrm{Ni}$, are also extremely elevated at the very top of the paleosol, as was the case for the calculations based on the dolostone parent material. Zirconium ( $\mathrm{Zr}$ ) is enriched by up to $20-40 \%$ at the top of the paleosol, similar the net increases determined based on the dolostone parent material (Fig. 11H).

\section{Interpretations and discussion}

\subsection{Modern Vertisol}

The upper $180 \mathrm{~cm}$ of the Houston Black pedon shows evidence for negative strain, or net soil volume loss, due to translocation of mobile chemical constituents, whereas the lower $20-30 \mathrm{~cm}$ has experienced positive strain, or net soil volume gain, probably due to displacive crystallisation of pedogenic calcite (Fig. $10 \mathrm{~A})$. Greater volume loss $(75-80 \%)$ is calculated assuming immobile $\mathrm{Zr}$ as compared with volume losses assuming immobile $\mathrm{TiO}_{2}(50 \%)$. Calculations made after correction for carbonate dilution indicate slightly lower volume losses for each respective immobile index element (Fig. 10A).

The upper portion of the Houston Black pedon (to a depth of $180 \mathrm{~cm}$ ) is characterised by net removal of

Fig. 11. Comparison of mass-balance reconstruction patterns of strain (volume change) and element translocations for the Pennington paleosol (Profiles 1 and 2), assuming either the subjacent marine dolostone was the parent, or that red clayshale was the parent, vs. depth in profiles. Element translocations (only Profile 2 shown) all assume immobile Ti during pedogenesis. To convert to percentage increases or decreases, multiply values $\times 100$. See text for discussion. (A, B) Strain (volume change during weathering) calculated assuming either immobile Ti or Zr, and calculated using both initial wt.\% and wt.\% corrected for carbonate dilution, as described in the text. (C) Translocations of Na and $\mathrm{K}$ calculated for both hypothesized parent materials. (D) Translocations of Al and Si. (E) Translocations of Ca and Mg. (F) Translocations of Sr and P. (G) Translocations of Fe and Mn. (H) Translocations of $\mathrm{Zr}$ and $\mathrm{Cr}$. 
$80 \% \mathrm{Na}, 50 \% \mathrm{~K}$, and $25 \% \mathrm{Al}$, whereas $\mathrm{Si}$ shows a modest net gain of 5-10\% (Fig. 10B). Inflections in the transport functions of these elements are noted at, and below, the interface of the lowest calcic horizon (BCk) and the Cr horizon, in other words, at a critical depth determined by vadose zone hydrology and the degree to which evaporation exceeds precipitation. The elements S (90\% loss), $\mathrm{Ca}$ (80\% loss), $\mathrm{Mg}$ (75\% loss), $\mathrm{P}$ (25\% loss), and $\mathrm{Sr}$ (98\% loss) exhibit similar behavior, with net decreases due to leaching in the upper $180 \mathrm{~cm}$ of the soil, respectively (Fig. 10C,D).

The redox sensitive elements $\mathrm{Fe}, \mathrm{Mn}, \mathrm{Cu}$, and $\mathrm{Cr}$ exhibit more complex transport functions (Fig. 10D,E; $\mathrm{Ba}$ covaries with $\mathrm{Mn}$ and is also plotted). Significant removal of $30 \% \mathrm{Fe}$ from all but the lowest portions of the pedon suggests overall lower Eh conditions developing during times of soil saturation. The more complex patterns of net positive gains in Mn $(200 \%), \mathrm{Ba}$ $(300 \%), \mathrm{Cu}(300 \%)$, and $\mathrm{Cr}(250 \%)$, which show strong covariation, reflect their stabilisation in a range of minerals and oxidation states. For example, Mn may be stabilised in carbonate in calcareous subsoils, limiting its depletion in the pedon. $\mathrm{Mn}$ and $\mathrm{Ba}$ are also components of todorokite, a hydrated complex manganese oxide that readily forms in Vertisols (Dixon, 1996). The losses of other redox-sensitive trace elements such as Co (45\%) and As (5-10\%) (Fig. 10F), and of $\mathrm{V}, \mathrm{Ni}$, and $\mathrm{Pb}$ (not shown), generally mirrors that of Fe. Complexation and sequestration of trace metals such as Co and Zn (not shown) in various Mn oxides (White and Dixon, 1996) can be similarly interpreted. The trace elements suggest common development of low-Eh conditions in the pedon during times of soil saturation and consequent trace element mobility. The large net gains $(50-75 \%)$ of the large ion lithophile element $\mathrm{Rb}$ (Fig. 10F) follows that of $\mathrm{Mn}, \mathrm{Ba}, \mathrm{Cu}$, and $\mathrm{Cr}$, with net additions throughout the entire pedon. The net additions of $\mathrm{Ba}$ and $\mathrm{Rb}$ apparently reflect accumulating clay during pedogenesis of chalk, whereas the net additions of $\mathrm{Zr}$ reflect additions of detrital silt-sized zircon grains (Fig. 10E), possibly from the High Plains of western Texas.

\subsection{Paleosol}

The mass-balance geochemical results for strain, or volume change during weathering, assuming immobile $\mathrm{Ti}$, are of the same range $(20-50 \%)$ for both the paleosol and the modern Vertisol, assuming that either the subjacent dolostone or nonpedogenic, noncalcareous red clayshale were the parent material for the paleosol (Figs. 10A and 11A,B). Both the paleosol and the modern Vertisol exhibit net negative translocations of the same range (20-90\%) for many of the alkali and alkaline earth elements, including $\mathrm{Na}, \mathrm{Ca}, \mathrm{Mg}$, and $\mathrm{Sr}$, with modest net gains localised near the bases of the profiles (Figs. 10B-D and $11 \mathrm{C}, \mathrm{E}, \mathrm{F})$. These patterns can only be explained by leaching of these elements during weathering and pedogenesis, and their precipitation in gypsum or calcite at depth in the profile. Net losses of redoxsensitive elements, such as $\mathrm{Fe}, \mathrm{Mn}$, and $\mathrm{Cr}$, reflect gley (low redox) conditions established during rising water table associated with poor drainage and ponding in the paleosol (Figs. 10D,E and 11G,H). Many elements, such as P (Fig. 11F), Fe (Fig. 11G), and S, $\mathrm{Cu}, \mathrm{Co}, \mathrm{V}$, and $\mathrm{Ni}$ (not shown), are extremely elevated at the top of the paleosol, where there is evidence of pyritisation associated with marine transgression and burial by the overlying marine carbonate beds.

The modern Vertisol has apparently experienced additional inputs of siliciclastic material from a source other than the underlying chalk, as evidenced by the field (Appendix A) and petrographic data (Fig. 8), as well as by geochemistry. The high $\mathrm{Zr}$ content of the soil compared with the underlying chalk, the higher strain values calculated assuming immobile $\mathrm{Zr}$, and the large net positive translocation of $\mathrm{Zr}$ (and smaller positive translocation of $\mathrm{Si}$ ) are indicative of these external additions (Figs. 9A and 10A,B). The paleosol also shows geochemical evidence for additional detrital siliciclastic inputs, such as higher $\mathrm{Zr}$ content than the dolostone, generally higher strain values calculated assuming immobile $\mathrm{Zr}$, and positive translocation for $\mathrm{Zr}$ (Figs. 9A and 11A,B,H). The red clayshale parent proxy, in contrast, has concentrations of both $\mathrm{Zr}$ and $\mathrm{TiO}_{2}$ that are more similar to those in the paleosol, produces lower estimates of strain, and more conservative translocation values (Figs. 9, 10 and 11). Thus $\mathrm{Zr}$ is apparently a poor choice for an immobile index element in mass-balance of modern Vertisols, and by analogy in paleoVertisols as well, because of the mobility of detrital silt- and very fine sand-sized zircon grains to both fluvial and aeolian transport 
processes, as was noted in previous studies (Driese et al., 2000; Stiles, 2001).

\section{Conclusions}

A drab-coloured paleosol directly overlying marine dolostone in the Pennington Formation near Sparta, Tennessee contains pedogenic features that compare favorably with those observed in a modern carbonate-parented Vertisol from Texas. Shrinking and swelling of clays due to wetting and drying cycles resulted in formation of pedogenic slickensides, angular to sub-angular peds and wedge-shaped structural aggregates. The petrography of the paleosol is characterised by a sepic-plasmic fabric, pyrite and siderite crystals, birefringent clays, stress cutans outlining peds, lenticular and rosette gypsum, and $\mathrm{Fe} /$ $\mathrm{Mn}$ concentrations. Weathered dolostone clasts are common near the lower contact between paleosol and dolostone and are visible in both outcrop and thin section.

The subjacent dolostone was initially interpreted as the parent material for the Pennington paleosol because it lies directly beneath the paleosol and shows evidence of pedogenesis; based on evidence from mass-balance geochemical reconstruction, petrographic thin section analysis, and insoluble residue content this hypothesis is possible. If true, then the thickness of dolostone required was about $4 \times$ the thickness of the preserved paleosol. The paleosol could thus represent a residual soil, in which case it records a long period of exposure of the subjacent dolostone to weathering. However, a more likely scenario is that there was deposition of siliciclastic material onto the dolostone prior to major onset of pedogenesis. Clayshale is considered more probable parent material for the paleosol based on the greater similarity of $\mathrm{TiO}_{2}$ and $\mathrm{Zr}$ contents between the shale and the paleosol, as well as less calculated volume and mass losses during weathering. A period of erosion, accompanying marine transgression and flooding, terminated pedogenesis and truncated the paleosol, prior to resumption of marine carbonate deposition. Care must therefore be exercised in interpreting parent material for paleosols occurring in mixed siliciclastic-carbonate sequences. Although most claystone paleosols probably form from least-weathered subjacent material, one should not automatically assume that this is true, especially if carbonate strata occur beneath these paleosols.

\section{Acknowledgements}

This project is partly based on a Senior Honors thesis by J.R.J. and was supported by National Science Foundation Grant EAR-9814607 (awarded to S.G.D., C.I. Mora, and L.C.N.). Dr. L.P. Wilding (Texas A\&M University) and C.A. Stiles (University of Tennessee) provided valuable insight and comments. We thank A.C. Robinson for providing access to unpublished data and for running XRF analysis and C.A. Stiles for assistance with insoluble residue measurements. We also thank G. Retallack and E. Bestland for their thoughtful reviews of an earlier version of this manuscript.

\section{Appendix A. Description of Houston Black series soil at Riesel Blackland Research Center, Riesel, TX}

TAXONOMIC CLASS: Fine, smectitic, thermic Udic Haplustert

TYPICAL PEDON: At the center of a gilgai microlow, within pasture of Riesel Blackland Research Center, Riesel, TX. (Colors are for moist soil). Note: $<1 \%$ siliceous subrounded pebbles, $2 \mathrm{~mm}-1$ $\mathrm{cm}$ diameter, throughout solum. Described by L.C. Nordt and S.G. Driese.

A1: $0-13 \mathrm{~cm}$; 10 YR 2/1 clay, moist; moderate fine subangular blocky structure; very firm, very sticky and plastic; many fine roots; common very fine pores; common to few $3 \mathrm{~mm}$ worm casts, burrows and pellets; few fragments of snail shells; moderately effervescent; moderately alkaline; gradual wavy boundary.

A2: $13-34 \mathrm{~cm} ; 2.5$ Y 5/3 to 2.5 Y 2.5/1 clay, moist; moderate fine and very fine subangular blocky peds; very firm, very sticky and very plastic; common fine and few medium roots; common very fine pores; moderate to strong effervescence; moderately alkaline; gradual wavy boundary.

Bss1: $34-67 \mathrm{~cm} ; 2.5 \mathrm{Y} 3.5 / 1$ clay, moist; strong coarse angular blocky natural fragments that form wedge shaped peds, very firm, very sticky and very plastic; few fine roots; common very fine pores; 
common distinct slickensides up to $20-40^{\circ}$ dip and spaced 3-4 cm, strong effervescence; moderately alkaline; gradual wavy boundary.

Bss2: $67-107 \mathrm{~cm}$; 2.5Y 3/1 clay, moist; similar to Bss1 but has weak fine prismatic to moderate angular blocky structure; many prominent intersecting slickensides up to $60^{\circ}$ dip and spaced $<1 \mathrm{~cm}$, gradual wavy boundary.

Bss3: $107-139 \mathrm{~cm}$; similar to Bss2, but has has prominent intersecting slickensides up to $20-40^{\circ}$ dip and spaced 3-4 cm; with large vertical fissure or krotovina filled with $2.5 \mathrm{Y} 7 / 3$ to $10 \mathrm{YR} 6 / 8$ material containing up to $1 \%$ carbonate; gradual wavy boundary.

Bssk: $139-189 \mathrm{~cm}$; coarsely and distinctly mottled $2.5 \mathrm{Y} 4 / 1$ clay; $10 \%$ pencil-like $2.5 \mathrm{Y} 7 / 3$ and $10 \mathrm{YR} 6 /$ 8 mottles; moderate medium and coarse angular blocky natural fragments that form wedge-shaped peds; very firm, very sticky and very plastic; few very fine roots and pores; many prominent slickensides, many intersecting slickensides up to $70^{\circ}$ dip and spaced $<1 \mathrm{~cm}, 2-3 \%$ fine and medium calcium soft carbonate masses up to $1 \mathrm{~cm}$ diameter, with hard cores up to $2 \mathrm{~mm}$; strongly effervescent; moderately alkaline; gradual wavy boundary.

BCk: $189-212 \mathrm{~cm}$; coarsely and distinctly mottled $85 \% 10$ YR $4 / 1$ and $10 \% 2.5$ Y $8 / 1$ to 10 YR $7 / 8$ clay; weak very coarse angular blocky peds parting to medium angular blocky peds; very firm, very sticky and very plastic; very few very fine roots and pores; many prominent slickensides up to $20^{\circ}$ dip and spaced $1-5 \mathrm{~cm}, 1 \%$ fine and medium calcium soft carbonate masses up to $1 \mathrm{~cm}$ diameter, with hard cores up to $2 \mathrm{~mm}$; strongly effervescent; strongly alkaline; clear wavy boundary.

Cr: $212-230+\mathrm{cm}$; coarsely and distinctly mottled $85 \% 2.5 \mathrm{Y} 7 / 4$ clay to saprolitized chalk, with $15 \%$ $2.5 \mathrm{Y} 5 / 2$ inclusions of clay; weak medium to very coarse angular blocky peds, but with regions of preserved rock structures; very few very fine roots and pores; violently effervescent; strongly alkaline; gradual wavy boundary.

Appendix B. Geochemical data (XRF, in wt.\%) and bulk density data $\left(\mathrm{g} / \mathrm{cm}^{3}\right)$ from Pennington paleosol Profiles 1 and 2 and red clayshale (red) at Sparta, TN

\begin{tabular}{lrrrrrrrrrrrr}
\hline $\begin{array}{l}\text { Depth } \\
\text { (cm) }\end{array}$ & $\mathrm{Na}_{2} \mathrm{O}$ & $\mathrm{MgO}$ & $\mathrm{Al}_{2} \mathrm{O}_{3}$ & $\mathrm{SiO}_{2}$ & $\mathrm{P}_{2} \mathrm{O}_{5}$ & $\mathrm{~S}$ & $\mathrm{~K}_{2} \mathrm{O}$ & $\mathrm{CaO}$ & $\mathrm{TiO}_{2}$ & $\mathrm{~V}$ & $\mathrm{Cr}$ & $\mathrm{MnO}$ \\
$\begin{array}{l}\text { Profile } \\
0\end{array}$ & & & & & & & & & & & & \\
-5 & 0.91 & 6.90 & 24.27 & 47.70 & 0.28 & 0.72 & 2.22 & 1.85 & 1.16 & 0.009 & 0.007 & 0.105 \\
-15 & 0.90 & 6.89 & 19.49 & 49.05 & 0.19 & 0.51 & 3.15 & 5.73 & 0.86 & 0.017 & 0.008 & 0.061 \\
-25 & 0.55 & 3.89 & 19.49 & 49.05 & 0.19 & 0.51 & 3.15 & 5.73 & 0.86 & 0.017 & 0.008 & 0.061 \\
-35 & 0.54 & 3.24 & 21.86 & 62.76 & 0.09 & 0.00 & 4.69 & 0.24 & 1.09 & 0.007 & 0.007 & 0.055 \\
-45 & 0.55 & 3.27 & 22.18 & 62.48 & 0.11 & 0.07 & 4.83 & 0.23 & 1.06 & 0.002 & 0.007 & 0.061 \\
-55 & 0.35 & 20.17 & 5.98 & 8.68 & 0.11 & 0.07 & 5.06 & 0.26 & 1.03 & 0.002 & 0.007 & 0.057 \\
-60 & 0.41 & 16.67 & 7.45 & 18.47 & 0.06 & 0.20 & 0.69 & 29.24 & 0.18 & 0.005 & 0.008 & 0.056 \\
-65 & 0.17 & 17.32 & 5.83 & 21.04 & 0.03 & 0.13 & 0.76 & 26.50 & 0.24 & 0.000 & 0.007 & 0.038
\end{tabular}

Profile 2

\begin{tabular}{lrrrrrrrrrrrr}
0 & 0.90 & 9.80 & 22.00 & 38.19 & 0.32 & 0.75 & 1.23 & 4.48 & 1.09 & 0.010 & 0.006 & 0.119 \\
-5 & 0.65 & 3.68 & 23.73 & 61.36 & 0.09 & 0.04 & 4.91 & 0.50 & 1.17 & 0.010 & 0.009 & 0.062 \\
-15 & 0.64 & 3.43 & 22.34 & 62.58 & 0.15 & 0.00 & 4.71 & 0.41 & 1.12 & 0.009 & 0.007 & 0.043 \\
-25 & 0.48 & 3.39 & 21.44 & 63.33 & 0.11 & 0.00 & 4.72 & 0.41 & 1.10 & 0.007 & 0.007 & 0.052 \\
-35 & 0.63 & 3.41 & 21.79 & 63.61 & 0.10 & 0.00 & 4.98 & 0.46 & 1.07 & 0.005 & 0.007 & 0.054 \\
-45 & 0.57 & 5.99 & 17.62 & 50.23 & 0.13 & 0.06 & 4.10 & 5.95 & 0.87 & 0.014 & 0.007 & 0.053 \\
-55 & 0.48 & 14.26 & 9.53 & 26.56 & 0.09 & 0.09 & 1.94 & 19.77 & 0.51 & 0.030 & 0.007 & 0.049 \\
-60 & 0.38 & 17.97 & 6.70 & 19.18 & 0.05 & 0.06 & 0.85 & 26.55 & 0.30 & 0.012 & 0.007 & 0.039 \\
Red & 1.09 & 4.46 & 22.39 & 60.53 & 0.17 & 0.002 & 4.48 & 1.55 & 0.86 & 0.010 & 0.007 & 0.054 \\
\hline
\end{tabular}




\section{References}

Ashley, G.R., Driese, S.G., 2000. Paleopedology and paleohydrology of a volcaniclastic paleosol: Implications for Early Pleistocene paleoclimate record, Olduvai Gorge, Tanzania. Journal of Sedimentary Research 70, 1065-1080.

Birkeland, P.W., 1999. Soils and Geomorphology, 3rd edn. Oxford Univ. Press, New York, 430 pp.

Blake, G.R., Hartge, K.H., 1986. Bulk density. In: Klute, A. (Eds.), Methods of Soil Analysis Part I-Physical and Mineralogical Methods, 2nd edn. Soil Science Society of America, Agronomy, Monologue, vol. 9, pp. 363-375.

Brewer, R., 1976. Fabric and Mineral Analysis of Soils R.E. Krieger Publishing, New York, 482 pp.

Brimhall, G.H., Lewis, C.J., Ague, J.J., Dietrich, W.E., Hampel, J., Teague, T., Rix, P., 1988. Metal enrichment in bauxites by deposition of chemically mature aeolian dust. Nature 333, 819-824.

Brimhall, G.H., Lewis, C.J., Ford, C., Bratt, J., Taylor, G., Warin, O., 1991a. Quantitative geochemical approach to pedogenesis: importance of parent material reduction, volumetric expansion, and eolian influx in lateritization. Geoderma 51, 51-91.

Brimhall, G.H., Chadwick, O.A., Lewis, C.J., Compston, W., Williams, I.S., Danti, K.J., Dietrich, W.E., Power, M., Hendricks, D., Bratt, J., 1991b. Deformational mass transfer and invasive processes in soil evolution. Science 255, 695-702.
Buol, S.W., Hole, F.D., McCracken, R.J., Southard, R.J., 1997. Soil Genesis and Classification, 3rd edn. Iowa State Univ. Press, Ames, 527 pp.

Caudill, M.R., Mora, C.I., Tobin, K.J., Driese, S.G., 1992. Preliminary interpretations of paleosols associated with Late Mississippian marginal marine deposits, Pennington Formation, Monterey, Tennessee. In: Driese, S.G., Mora, C.I., Walker, K.R. (Eds.), Paleosols, Paleoweathering Surfaces, and Sequence Boundaries. University of Tennessee Studies in Geology, vol. 21. Knoxville, pp. 57-78.

Caudill, M.R., Driese, S.G., Mora, C.I., 1996. Preservation of a paleo-Vertisol and an estimate of late Mississippian paleo-precipitation. Journal of Sedimentary Research 66, 58-70.

Caudill, M.R., Driese, S.G., Mora, C.I., 1997. Physical compaction of vertic palaeosols: implications for burial diagenesis and palaeoprecipitation estimates. Sedimentology 44, 673685.

Cerling, T.E., 1991. Carbon dioxide in the atmosphere: evidence from Cenozoic and Mesozoic paleosols. American Journal of Science 291, 377-400.

Coulombe, C.E., Dixon, J.B., Wilding, L.P., 1996. Mineralogy and chemistry of Vertisols. In: Ahmad, N., Mermut, A. (Eds.), Vertisols and Technologies for their Management. Developments in Soil Science, vol. 24. Elsevier, New York, pp. 115-200.

Dixon, J.B., 1996. Manganese oxides in soils and weathered rocks.

\begin{tabular}{rlllllllllllll}
\hline $\mathrm{Fe}_{2} \mathrm{O}_{3}$ & $\mathrm{Co}$ & $\mathrm{Ni}$ & $\mathrm{Zn}$ & $\mathrm{Pb}$ & $\mathrm{As}$ & $\mathrm{Rb}$ & $\mathrm{Sr}$ & $\mathrm{Zr}$ & $\mathrm{Ba}$ & $\mathrm{Cu}$ & Total & $\begin{array}{l}\text { Bulk } \\
\text { density }\end{array}$ \\
& & & & & & & & & & & & & \\
11.16 & 0.007 & 0.015 & 0.000 & 0.022 & 0.002 & 0.017 & 0.014 & 0.014 & 0.035 & 0.007 & 97.43 & 1.74 \\
5.41 & 0.001 & 0.004 & 0.000 & 0.003 & 0.001 & 0.016 & 0.012 & 0.013 & 0.056 & 0.002 & 92.38 & 2.05 \\
5.41 & 0.001 & 0.004 & 0.000 & 0.003 & 0.001 & 0.016 & 0.012 & 0.013 & 0.056 & 0.002 & 92.38 & 2.02 \\
5.59 & 0.002 & 0.003 & 0.000 & 0.001 & 0.000 & 0.023 & 0.011 & 0.021 & 0.081 & 0.000 & 100.43 & 2.03 \\
6.38 & 0.002 & 0.004 & 0.000 & 0.002 & 0.000 & 0.023 & 0.011 & 0.019 & 0.080 & 0.002 & 100.53 & 2.07 \\
6.50 & 0.002 & 0.004 & 0.000 & 0.001 & 0.000 & 0.023 & 0.009 & 0.017 & 0.090 & 0.000 & 99.47 & 1.97 \\
3.27 & 0.001 & 0.002 & 0.000 & 0.002 & 0.001 & 0.000 & 0.087 & 0.005 & 0.014 & 0.001 & 68.94 & 2.18 \\
3.24 & 0.001 & 0.001 & 0.000 & 0.001 & 0.001 & 0.003 & 0.056 & 0.006 & 0.027 & 0.000 & 73.34 & 2.36 \\
2.68 & 0.001 & 0.001 & 0.000 & 0.001 & 0.001 & 0.001 & 0.074 & 0.007 & 0.018 & 0.000 & 74.85 & 2.20 \\
& & & & & & & & & & & & \\
& & & & & & & & & & & & \\
14.13 & 0.021 & 0.027 & 0.000 & 0.031 & 0.002 & 0.013 & 0.015 & 0.009 & 0.018 & 0.014 & 93.17 & 1.93 \\
5.68 & 0.002 & 0.004 & 0.000 & 0.004 & 0.001 & 0.023 & 0.012 & 0.023 & 0.097 & 0.001 & 102.06 & 2.06 \\
4.76 & 0.001 & 0.003 & 0.000 & 0.001 & 0.001 & 0.023 & 0.012 & 0.024 & 0.085 & 0.002 & 100.35 & 2.08 \\
5.76 & 0.002 & 0.004 & 0.000 & 0.002 & 0.001 & 0.022 & 0.011 & 0.023 & 0.088 & 0.003 & 100.97 & 2.00 \\
6.22 & 0.002 & 0.004 & 0.000 & 0.001 & 0.000 & 0.023 & 0.011 & 0.020 & 0.088 & 0.002 & 102.48 & 2.09 \\
5.68 & 0.001 & 0.003 & 0.000 & 0.001 & 0.000 & 0.017 & 0.019 & 0.014 & 0.077 & 0.001 & 91.41 & 1.94 \\
4.49 & 0.001 & 0.002 & 0.000 & 0.002 & 0.001 & 0.006 & 0.033 & 0.006 & 0.034 & 0.000 & 77.90 & 2.35 \\
3.23 & 0.001 & 0.001 & 0.000 & 0.002 & 0.001 & 0.002 & 0.049 & 0.004 & 0.018 & 0.000 & 75.40 & 2.31 \\
6.61 & 0.002 & 0.005 & 0.000 & 0.001 & 0.000 & 0.020 & 0.017 & 0.014 & 0.108 & 0.000 & 102.37 & 2.31 \\
\hline
\end{tabular}




\begin{tabular}{|c|c|c|c|c|c|c|c|c|c|c|c|c|}
\hline Depth & $\mathrm{Na}_{2} \mathrm{O}$ & $\mathrm{MgO}$ & $\mathrm{Al}_{2} \mathrm{O}_{3}$ & $\mathrm{SiO}_{2}$ & $\mathrm{P}_{2} \mathrm{O}_{5}$ & $\mathrm{~S}$ & $\mathrm{~K}_{2} \mathrm{O}$ & $\mathrm{CaO}$ & $\mathrm{TiO}_{2}$ & $\mathrm{~V}$ & $\mathrm{Cr}$ & $\mathrm{MnO}$ \\
\hline-10 & 0.49 & .59 & 11.52 & 58.02 & 0.13 & 0.10 & 0.92 & 12.12 & 0.58 & 0.016 & 9 & 0.060 \\
\hline-20 & 0.73 & 1.62 & 11.47 & 58.68 & 0.13 & 0.10 & 0.88 & 12.55 & 0.58 & .015 & .009 & 0.059 \\
\hline-30 & 0.44 & 1.57 & 10.97 & 58.92 & 0.13 & 0.10 & 0.86 & 12.77 & 0.57 & 012 & 010 & 0.061 \\
\hline-40 & 0.51 & 1.67 & 11.00 & 59.90 & 0.13 & 0.09 & 0.88 & 12.80 & 0.57 & 0.015 & 0.009 & 0.061 \\
\hline-50 & 0.62 & 1.75 & 10.96 & 58.41 & 0.13 & 0.10 & 0.86 & 13.03 & 0.55 & 0.014 & 0.008 & 0.058 \\
\hline-60 & 0.49 & 1.62 & 11.33 & 55.48 & 0.13 & 0.09 & 0.84 & 12.90 & 0.54 & 0.013 & 0.012 & 0.090 \\
\hline-70 & 0.77 & 1.8 & 11.7 & 60.64 & 0.1 & 0.11 & 0.87 & 13.51 & 0 & 0. & 0 & 0.088 \\
\hline-80 & 0.67 & 1.81 & 11.57 & 60.03 & 0.13 & 0.10 & 0.88 & 13.44 & 56 & 0.022 & 0.011 & 0.085 \\
\hline-90 & 0.58 & 1.61 & 11.19 & 59.25 & 0.13 & 0.10 & 0.87 & 12.88 & 0.57 & 0.016 & 0.010 & 0.078 \\
\hline-100 & 0.58 & 1.60 & 11.04 & 56.81 & 0.13 & 0.10 & 0.86 & 13.88 & 0.55 & 0.017 & 0.007 & 0.054 \\
\hline-110 & 0.70 & 1.65 & 11.02 & 58.81 & 0.13 & 0.11 & 0.87 & 14.19 & 0.56 & 0.021 & 0.009 & 0.056 \\
\hline-120 & 0.71 & 1.61 & 10.60 & 57.62 & 0.1 & 0.12 & 0.83 & 15.24 & 0.54 & 0.014 & 0.008 & 0.048 \\
\hline-130 & 0.68 & 1.74 & 10.81 & 54.43 & 0.12 & 0.12 & 0.84 & 15.51 & 0.51 & 0.018 & 0.006 & 0.062 \\
\hline-140 & 0.67 & 1.68 & 10.63 & 54.39 & 0.12 & 0.13 & 0.82 & 15.99 & 0.52 & 0.022 & 0.008 & 0.062 \\
\hline-150 & 0.69 & 1.61 & 10.77 & 56.30 & 0.12 & 0.11 & 0.83 & 14.84 & 0.53 & 0.019 & 0.009 & 0.054 \\
\hline-160 & 0.8 & 1.5 & & 55.30 & 0.1 & 0.12 & 0.82 & 15.06 & 0.53 & & 0.008 & 0.057 \\
\hline-170 & 0.64 & 1.58 & 10.25 & 58.40 & 0.13 & 0.11 & 0.81 & 14.88 & 0.53 & 0.014 & 0.008 & 0.056 \\
\hline-180 & 0.66 & 1.55 & 10.18 & 55.44 & 0.12 & 0.12 & 0.82 & 16.07 & 0.51 & 0.017 & 0.007 & 0.041 \\
\hline-190 & $1.3^{\circ}$ & 2.10 & 8.73 & 41.27 & 0.10 & 0.29 & 0.80 & 24.28 & 0.37 & 0.022 & 0.005 & 0.028 \\
\hline-200 & 1.65 & 2.54 & 7.28 & 29.44 & 0.08 & 0.43 & 0.78 & 29.02 & 0.29 & 0.025 & 0.003 & 0.017 \\
\hline-210 & 1.68 & 2.67 & 7.12 & 28.25 & 0.08 & 0.44 & 0.82 & 29.03 & 0.29 & 0.023 & 0.003 & 0.013 \\
\hline-220 & 1.74 & 2.76 & 7.11 & 27.07 & 0.08 & 0.46 & 0.89 & 29.17 & 0.28 & 0.025 & 0.001 & 0.011 \\
\hline
\end{tabular}

Agronomy Abstracts. American Society of Agronomy, Madison, WI, p. 321.

Driese, S.G., Foreman, J.L., 1992. Paleopedology and paleoclimatic implications of Late Ordovician vertic paleosols, southern Appalachians. Journal of Sedimentary Petrology 62, 71-83.

Driese, S.G., Mora, C.I., Cotter, E., Foreman, J.L., 1992. Paleopedology and stable isotope geochemistry of Late Silurian vertic paleosols, Bloomsburg Formation, central Pennsylvania. Journal of Sedimentary Petrology 62, 825-841.

Driese, S.G., Mora, C.I., Stiles, C.A., Joeckel, R.M., Nordt, L.C., 2000. Mass-balance reconstruction of a modern Vertisol: implications for interpreting the geochemistry and burial alteration of paleo-Vertisols. Geoderma 95, 179-204.

Dudal, R., Eswaran, H., 1988. Distribution, properties, and classification of Vertisols. In: Wilding, L.P., Puentes, R. (Eds.), Vertisols: Their Distibution, Properties, Classification, and Management. Texas A\&M University Press, College Station, pp. 1-22.

Fitzpatrick, E.A., 1993. Soil Microscopy and Micromorphology Wiley, New York, 304 pp.

Harding, S.D., 1995. The stratigraphy and paleoenvironments of paleosols and associated strata of the lower Pennington Formation (Upper Mississippian) at Sparta, Tennessee. Senior Honors Thesis. University of Tennessee-Knoxville, $41 \mathrm{pp}$.

Kunze, G.W., Templin, E.H., 1956. Houston Black Clay, the type
Grumosol: II. Mineralogical and chemical characterization. Soil Science Society of America Proceedings 20, 91-96.

Mason, J.A., Jacobs, P.M., 1998. Chemical and particle-size evidence for addition of fine dust to soils of the midwestern United States. Geology 26 (12), 1135-1138.

Mora, C.I., Driese, S.G., 1999. Palaeoclimatic significance and stable carbon isotopes of Palaeozoic red bed paleosols, Appalachian Basin, USA and Canada. In: Thiry, M., Simon-Coinçon, R. (Eds.), Palaeoweathering, Palaeosurfaces and Related Continental Deposits. International Association of Sedimentologists Special Publication, vol. 27, pp. 61-84.

Mora, C.I., Fastovsky, D.E., Driese, S.G., 1993. Geochemistry and Stable Isotopes of Paleosols: A Short Course Manual for the Annual Meeting of the Geological Society of America Convention. Department of Geological Sciences, Studies in Geology, vol. 23. University of Tennessee, Knoxville, 65 pp.

Mora, C.I., Driese, S.G., Colarusso, L.A., 1996. Middle to Late Paleozoic atmospheric $\mathrm{CO}_{2}$ from soil carbonate and organic matter. Science 271, 1105-1107.

Munsell Color Company, 1984. Munsell Rock-Color Chart. Macbeth Division of the Kollmorgen, Baltimore.

Olson, C.G., Ruhe, R.V., Mausbach, M.J., 1980. The Terra Rosa Limestone contact phenomena in karst, southern Indiana. Soil Science Society of America Journal 44, 1075-1079. 


\begin{tabular}{|c|c|c|c|c|c|c|c|c|c|c|c|c|c|}
\hline $\mathrm{Fe}_{2} \mathrm{O}_{3}$ & 0 & $\mathrm{Ni}$ & $\mathrm{Zn}$ & $\mathrm{Pb}$ & As & $\mathrm{Rb}$ & $\mathrm{Sr}$ & $\mathrm{Zr}$ & $\mathrm{Ba}$ & $\mathrm{u}$ & al & Horizons & $\begin{array}{l}\text { Bulk } \\
\text { density }\end{array}$ \\
\hline 66 & 0.001 & 003 & 000 & 001 & 001 & 007 & 009 & 34 & 042 & 0.001 & 9.32 & A1 & 1.61 \\
\hline 62 & 0.001 & .002 & 000 & 001 & .001 & 0.007 & 0.009 & 0.034 & & 0.002 & 90.55 & A2 & 1.55 \\
\hline 59 & 0.001 & 0.003 & 0.000 & 0.001 & .001 & .007 & 0.009 & 0.034 & 0.046 & 0.001 & 90.10 & A2 & 1.46 \\
\hline 62 & 0.001 & 0.002 & 0.000 & & 0.001 & & & & & & & & 1.33 \\
\hline 54 & 0.001 & 0.002 & 0.000 & 0.001 & 0.001 & 0.006 & 0.010 & & & 1 & & & .36 \\
\hline 61 & 0.001 & 0.003 & 0.001 & 0.002 & .001 & 0.007 & 0.010 & & & & & & 1.43 \\
\hline 67 & 0.001 & 0.003 & 0.000 & 2 & .001 & 0.007 & 0.010 & & & 0.002 & 94.07 & & 1.39 \\
\hline 65 & 0.001 & 0.003 & 0.000 & 0 & 0 . & 7 & 10 & & & & & & \\
\hline n & 0.00 & 0.0 & 0.0 & 0 & & & 0.010 & & & & & & 5 \\
\hline 53 & 0.00 & 0 & 0.0 & 1 & 001 & 7 & 0.011 & & & 1 & & & \\
\hline 56 & 0.001 & 0.002 & 0.000 & 0.0 & 0.001 & 0.007 & 0.012 & 3 & 0.038 & 0.0 & 91.77 & $\mathrm{~B}$ & 1.53 \\
\hline 35 & 0.001 & 0.002 & 0.000 & 0.001 & 0.001 & 0.006 & 0.012 & & 0.036 & & 90.91 & & 1.62 \\
\hline 40 & 0.001 & 0.002 & 0.000 & & 0.001 & 0.006 & 0.012 & & 0.038 & & & & \\
\hline & & & & & & & & & & & & & \\
\hline .39 & 0.001 & 0.002 & 0.000 & 0.001 & 0.001 & 0.006 & 0.012 & 0.033 & 0.045 & 0.001 & 89.39 & Bssk & 1.68 \\
\hline 35 & 0.001 & 0.002 & 0.000 & 0.001 & 0.001 & 0.006 & 0.012 & 0.032 & 0.039 & 0.001 & 88.82 & Bssk & 1.73 \\
\hline 32 & 0.001 & 0.002 & 0.000 & 0.001 & 0.001 & 0.006 & 0.012 & 0.036 & 0.040 & 0.002 & 90.83 & Bssk & 1.64 \\
\hline 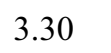 & 0.001 & & & & & & & & & & & & \\
\hline 18 & 0.001 & 0.002 & 0.000 & 0.001 & 0.001 & 0.003 & 0.026 & 0.014 & 0.017 & 0.001 & 82.17 & BCK & 1.25 \\
\hline .33 & 0.001 & 0.001 & 0.000 & 0.001 & 0.000 & 0.002 & 0.032 & 0.006 & 0.006 & 0.001 & 73.97 & $\mathrm{BCk}$ & 1.35 \\
\hline .52 & 0.001 & 0.001 & 0.000 & 0.001 & 0.000 & 0.002 & 0.036 & 0.006 & 0.004 & 0.000 & 72.99 & $\mathrm{BCk}$ & 1.38 \\
\hline 2.48 & 0.001 & 0.002 & 0.000 & 0.001 & 0.000 & 0.002 & 0.042 & 0.006 & 0.006 & 0.000 & 72.14 & $\mathrm{Cr}$ & 1.57 \\
\hline
\end{tabular}

Retallack, G.J., 1988. Field recognition of paleosols. In: Reinhardt, J., Sigleo, W.R. (Eds.), Paleosols and Weathering through Geologic Time. Geological Society of America, Special Publication, vol. 216, pp. 1-20.

Retallack, G.J., 1994. The environmental factor approach to the interpretation of paleosols. In: Amundson, R., et al., (Eds.), Factors of Soil Formation: Fiftieth Anniversary Retrospective. Soil Science Society of America Special Publication, vol. 33, pp. 31-64.

Retallack, G.J., 2001. Soils of the Past: An Introduction to Paleopedology, 2nd edn. Blackwell, Oxford, $404 \mathrm{pp}$.

Robinson, A.C., 2001. A chronosequence study of modern Vertisols and application to Paleozoic paleoVertisols. Unpublished MS Thesis, University of Tennessee, Knoxville, 240 pp.

Robinson, A.C., Driese, S.G., Mora, C.I., Robey, E.M., Nordt, L.C., Wilding, L.P., 2000. A chronosequence study of modern Vertisols - analog for Paleozoic claystone paleosols. Abstracts with Programs, vol. 32, no. 2. Geological Society of America, Boulder, Colorado, p. A-70.

Scotese, C.R., Bambach, R.K., Barton, C., Van Der Voo, R., Ziegler, A.M., 1979. Paleozoic base maps. Journal of Geology 87, $217-$ 277.
Soil Survey Staff, 1995. Soil Survey Laboratory Information Manual. Soil Survey Investigations Report 45, Version 1.0. US Government Printing Office, Washington, DC, 305 pp.

Soil Survey Staff, 1998. Keys to Soil Taxonomy, 8th edn. US Government Printing Office, Washington, DC, 324 pp.

Stiles, C.A., 2001. Pedogenic relationships in a Texas Vertisol climosequence defined by geochemical mass balance of whole soil and chemistry of iron-manganese nodules. Unpublished $\mathrm{PhD}$ Dissertation, University of Tennessee, Knoxville, 264 pp.

Stiles, C.A., Mora, C.I., Driese, S.G., 2001. Pedogenic iron-manganese nodules in Vertisols: a new proxy for paleoprecipitation? Geology 29 (10), 943-946.

Templin, E.H., Mowery, I.C., Kunze, G.W., 1956. Houston Black Clay, the type Grumosol: I. Field morphology and geography. Soil Science Society of America Proceedings 20, 88-90.

White, G.N., Dixon, J.B., 1996. Iron and manganese distribution in nodules from a young Texas Vertisol. Soil Science Society of America Journal 60, 1254-1262.

Ziegler, A.M., Scotese, C.R., McKerrow, W.S., Johnson, M.E., Bambach, R.K., 1979. Paleozoic paleogeography. Annual Review of Earth and Planetary Sciences 7, 473-502. 